\title{
EDUCAÇÃO AMBIENTAL: UMA PERSPECTIVA METODOLÓGICA EMPREGADA PELO PROJETO NATIVAS NO CAMPUS DA UFRN
}

\author{
Ricardo Teixeira Gregório de Andrade \\ Tecnólogo em Controle Ambiental, CEFET-RN. \\ rtnatal@gmail.com
}

Adriana Cláudia Câmara da Silva

Bióloga. Mestre em Bioecologia Aquática pela Universidade Federal do Rio Grande do

Norte - UFRN.

adriana@cefetrn.br

\section{RESUMO}

O presente trabalho, tendo como tema 'Educação Ambiental: uma perspectiva metodológica empregada pelo Projeto Nativas no Campus da UFRN', é dedicado ao estudo da educação ambiental realizada através da prática de arborização e abordagem teórica correlata. Foram abordadas cinco atividades de educação ambiental, realizadas no Campus Universitário da UFRN, no período de julho/2005 a julho/2006, e contemplados estudantes de escolas públicas e particulares, na faixa etária de 11 a 15 anos. O objetivo geral foi desenvolver a construção da educação ambiental com estudantes de escolas públicas e particulares através de uma perspectiva metodológica empregada pelo Projeto Nativas no Campus (PNC) - um projeto de extensão da Universidade Federal do Rio Grande do Norte (UFRN), que desenvolve atividades ambientais nos âmbitos social e acadêmico, por meio da prática de arborização urbana. A metodologia utilizada buscou integrar a educação informal à formal e consistiu em dois estágios: programação e efetivação. Esta última sendo desenvolvida em quatro momentos: recepção dos alunos, exposição teórica dos temas ligados ao meio ambiente, arborização e momento de interação. Os resultados obtidos têm por base a análise da metodologia aplicada quanto à sua funcionalidade, sendo expostos em função do comportamento observado nos estudantes e registros efetivados pelos mesmos (questionários e desenhos). Concluiu-se que a utilização dessa metodologia para a realização de atividades de educação ambiental foi válida. A temática arborização permitiu a abordagem de temas inerentes a educação ambiental com vasta abrangência, tanto no âmbito da educação formal, como também em destaque, da educação informal.

PALAVRAS-CHAVE: Educação ambiental, arborização, confecção de desenhos, Nativas no Campus - UFRN, Meio Ambiente.

\section{ENVIRONMENTAL EDUCATION: A METHODOLOGICAL PERSPECTIVE USED BY THE PROJETO NATIVAS NO CAMPUS, FROM UFRN}

\begin{abstract}
The present study, which theme is 'Environmental education: a methodological perspective used by the Projeto Nativas no Campus, from UFRN', is devoted to the environmental education realized through the planting practice and correlate theoretical approach. There were five activities, realized on the Campus from UFRN, from july/2005 to july/2006, within students from public and private schools, among 11 to 15 years old. The mainly objective was to develop the environmental education within students from private and
\end{abstract}


public schools from the Projeto Nativas no Campus (PNC) methodology - a extension project from the Universidade Federal do Rio Grande do Norte (UFRN), which develops environmental activities on social and academic ambits, by the urban planting practice. The methodology intended to integrate the informal and formal education and consisted on two phases: programming and execution. This last one developed in four moments: students' reception, theoretical exposition of environmental relationed themes, planting practice and integration. The results obtained are based on the functionality of this methodology, and exposed in relation to the student's behavior observed and records made by those (questioners and draws). This methodology was considered as valid. The planting thematic has permitted to aboard a vast content of themes related to the environmental education, thus on formal education as much as, on prominence, informal education.

KEY WORDS: Environmental education, Planting practice, Draws confection; Nativas no Campus - UFRN; Environment. 


\section{EDUCAÇÃO AMBIENTAL: UMA PERSPECTIVA METODOLÓGICA EMPREGADA PELO PROJETO NATIVAS NO CAMPUS DA UFRN}

\section{INTRODUÇÃO}

O presente estudo expõe um trabalho de educação ambiental desenvolvido com estudantes de escolas públicas e particulares, na faixa etária de 11 a 15 anos, através da prática da arborização e abordagem teórica correlata. A problemática a ser estudada é: 'A metodologia da prática da arborização e abordagem teórica é valida para a conscientização ambiental?'

As escolas contempladas foram as seguintes: Escola Estadual Lauro de Castro, Escola Estadual Presidente Café Filho, Escola Estadual Floriano Cavalcanti, o Centro Educacional Santo Agostinho, Escola Municipal Professora Francisca Ferreira de Souza e CDF Colégio e Curso - Unidade Deodoro. Foi detectado nas escolas um baixo índice de arborização e áreas verdes conservadas no terreno da escola. Os coordenadores das escolas afirmam procurarem desenvolver temáticas ligadas à educação ambiental inseridas nos conteúdos disciplinares. Entretanto, somente a Escola Estadual Presidente Café Filho possui um trabalho de educação ambiental realizado no âmbito informal, realizado em conjunto com um projeto denominado 'Projeto sementinha'.

O objetivo principal é desenvolver a construção da educação ambiental com estudantes de escolas públicas e particulares através de uma perspectiva metodológica empregada pelo Projeto Nativas no Campus (PNC). Visando almejar tal finalidade, podem ser enumerados os seguintes objetivos específicos: a) sensibilizar os estudantes pela realização de um trabalho de educação ambiental através da prática de arborização e suas decorrências; b) avaliação dos jogos, questionários e desenhos aplicados e confeccionados como mensuração da formação de uma consciência ambiental; c) proposição de uma atividade de aprendizado através do lazer e do lúdico; d) construção sistemática de um processo de crescimento pessoal e coletivo dentro dos momentos da atividade;

O capítulo Projeto "Nativas no Campus” (PNC) expõe sobre o projeto e suas finalidades, o qual foi meio de realização das atividades de educação ambiental desenvolvidas.

Na Metodologia estão descritos as áreas onde ocorreram as atividades, as formas empregadas nas realizações dos plantios e as atividades de educação ambiental.

Os resultados e as discussões expõem as ações desenvolvidas e são referenciados com base na pesquisa bibliográfica.

\section{A IMPORTÂNCIA DA EDUCAÇÃO AMBIENTAL PARA A SENSIBILIZAÇÃo ECOLÓGICA}

Uma criança ao nascer, já desperta para o conhecimento e interação com o meio. À medida que se desenvolve, ela passa a ampliar seu conhecimento através da educação, recebida por diversas frentes, e aprende a interagir com pessoas e ambientes diversos. Saviani (1993 apud PHILIPPI e PELICIONI 2002) declaram que "a educação em sentido amplo é um processo permanente que se inicia quando se nasce e que perpassa por toda a vida, 
preparando o cidadão para a vida social, na medida em que se aprendem todas as normas da sociedade e seus valores culturais”.

A educação, bem como o que cada ser carrega no íntimo, contribui para a formação do caráter, individual e coletivo. Segundo o Dicionário Aurélio (1999), o verbete educação é definido como: “(...)2. Processo de desenvolvimento da capacidade física, intelectual e moral da criança e do ser humano em geral, visando à sua melhor integração individual e social(...)”. Essa capacidade física, intelectual e moral do ser humano se traduz nas visões de mundo e nos valores pessoais e coletivos, que são responsáveis pelas ações praticadas e não praticadas em quase todos os níveis, incluído o nível ambiental.

Segundo Ulman (1982):

a educação consiste numa ação exercida por um ser humano sobre outro ser humano - mais freqüentemente, por um adulto sobre uma criança para permitir ao 'educado' a aquisição de certos traços culturais (saberes ou maneiras de agir tanto técnicas como morais), que os costumes, o sentimento ou uma convicção reflectiva consideram desejáveis.

A aprendizagem educacional, inicialmente, tem por base os pais que fomentam o afloramento dos sentimentos e ensinam as primeiras noções de comportamento íntimo, social e ambiental. Seqüencialmente, a educação passa a ser também recebida pela sociedade, através da própria vivência e da escolarização. "Embora a escola não exerça o papel de 'redentora' da sociedade, é, no entanto, a instituição que, junto com a família, deve criar a consciência cidadã das novas gerações (MIGOTTO, 2004, p. 20)”. Em Vasconcelos (2006), pode-se ver que Durkheim pensa que a educação é “como um meio importante de socialização que espalha valores no conjunto da sociedade, participa ativamente na formação de uma 'consciência coletiva' e, assim, se torna um 'princípio' de integração social” (DURKHEIM 1922, 1938 apud VASCONCELLOS, 2006).

Segundo Martins Junior (2006), “a educação torna-se central ao conceito de cidadania, tendo como papel fundamental transformar o homem em cavalheiro, ou seja, promover a conscientização necessária na evolução do sujeito como cidadão”.

É imensa a importância e responsabilidade da educação escolar na formação da índole de cada pessoa e seu papel social. "Por meio da educação, a transmissão dos valores, padrões e hábitos mentais de uma geração à outra está garantida de modo metódico" (VASCONCELLOS, 2006). Nesse sentido, a educação como um todo é molde da natureza humana pessoal e coletiva que rege os valores, padrões e hábitos dos indivíduos e de toda uma sociedade ao longo do tempo.

Na Conferência Internacional de Moscou, a UNESCO (1987) definiu:

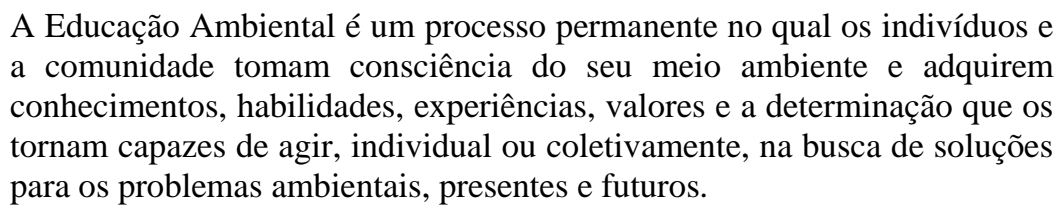

As conceituações sobre educação ambiental existem de várias formas, semelhantes e, inclusive, mais recentes. Embora a definição acima tenha sido idealizada há duas décadas, é perceptível que a mesma se mantém atual. O planeta Terra ainda sofre profundas alterações maléficas, fruto de uma falta de consciência ambiental. 
A educação ambiental se mostra uma alternativa concreta na consolidação da consciência ambiental e na formação de uma sociedade que permita uma maior abrangência de exploração das temáticas ambientais. Assim como é citado nos Parâmetros Curriculares Nacionais (BRASIL, 2001, p. 24), “a educação sozinha não é suficiente para mudar os rumos do planeta, mas é certamente condição necessária para tanto”, e:

"Todas as recomendações, decisões e tratados internacionais sobre o tema evidenciam a importância atribuída por lideranças de todo o mundo para a educação ambiental como meio indispensável para se conseguir criar e aplicar formas cada vez mais sustentáveis de interação sociedade-natureza e soluções para os problemas ambientais.”

Medina (1999) expõe que:

Não se trata tão-somente de ensinar sobre a natureza, mas de educar "para” e “com” a natureza; para compreender e agir corretamente ante os problemas das relações do homem com o ambiente; trata-se de ensinar sobre o papel do ser humano na biosfera, para a compreensão das complexas relações entre a sociedade e a natureza, e dos processos históricos que condicionam os modelos de desenvolvimento adotados pelos diferentes grupos sociais.

A educação ambiental, portanto, “é um processo de ensino-aprendizagem para o exercício da cidadania” (PHILIPPI e PELICIONI, 2002). A ela cabe construir novos valores e novas relações sociais e dos seres humanos com a natureza formando atitudes dentro de uma nova ótica, a da melhoria da qualidade de vida para todos os seres.

\section{PROJETO NATIVAS NO CAMPUS}

O Projeto "Nativas no Campus” (PNC) é um projeto de extensão universitária da UFRN Universidade Federal do Rio Grande do Norte, com o objetivo principal realizar uma arborização do campus universitário da UFRN, de forma paulatina e sustentável, e suscitar suas decorrências nos demais âmbitos sociais e acadêmicos, como educação ambiental, inclusão social, dentre outros.

Os objetivos específicos do PNC são:

a) contribuir para uma melhora na qualidade ambiental do Campus Universitário;

b) realizar uma arborização que atenda ao índice recomendado pela ONU (12 m² de área verde por habitante);

c) contribuir para o enriquecimento do aspecto paisagístico do Campus Universitário;

d) avaliar o crescimento e adaptação das árvores plantadas a partir da metodologia empregada;

e) avaliar o potencial das espécies plantadas para a arborização de diferentes setores urbanos (rua, praça, parque, etc), tendo como base o levantamento de dados sobre o porte, flores, frutos, dispersão de sementes, alimento para a fauna, afloramento de raízes, dentre outros;

f) realizar atividades de educação ambiental com jovens e crianças;

g) realizar terapia ocupacional com pacientes do setor público.

A estratégia abordada é a utilização de espaços urbanos para conservação de espécies vegetais ameaçadas de extinção, através do plantio de espécies nativas da mata atlântica. As espécies são escolhidas levando-se em conta dois fatores: a) sua representatividade e importância no bioma mata atlântica; b) disponibilidade nos hortos para doação. A 
utilização das espécies da mata atlântica faz o diferencial do projeto, visto que são as mais bem adaptadas às condições naturais locais, intrínsecas ao bioma. Visa-se adquirir a sustentabilidade da arborização realizada, através da constante manutenção das plantas, incluídos irrigação, adubação, poda e amarração.

O PNC é estruturado em uma coordenação geral e demais coordenações (manutenção, acompanhamento científico, educação ambiental, inclusão social, divulgação), compostas por equipes que desempenham funções específicas, porém interligadas. A coordenação de educação ambiental é a de maior relevância para este estudo e o exercício de suas atividades será abordado mais adiante.

\section{METODOLOGIA}

\subsection{Caracterização da Área}

A área de atuação do PNC é o Campus Universitário da UFRN, o qual se situa na Av. Senador Salgado Filho, 3000, Lagoa Nova, Natal. O Campus localiza-se ao lado do Parque Estadual Dunas de Natal (Figura 1), estando grande parte de seu perímetro em contato direto com este.

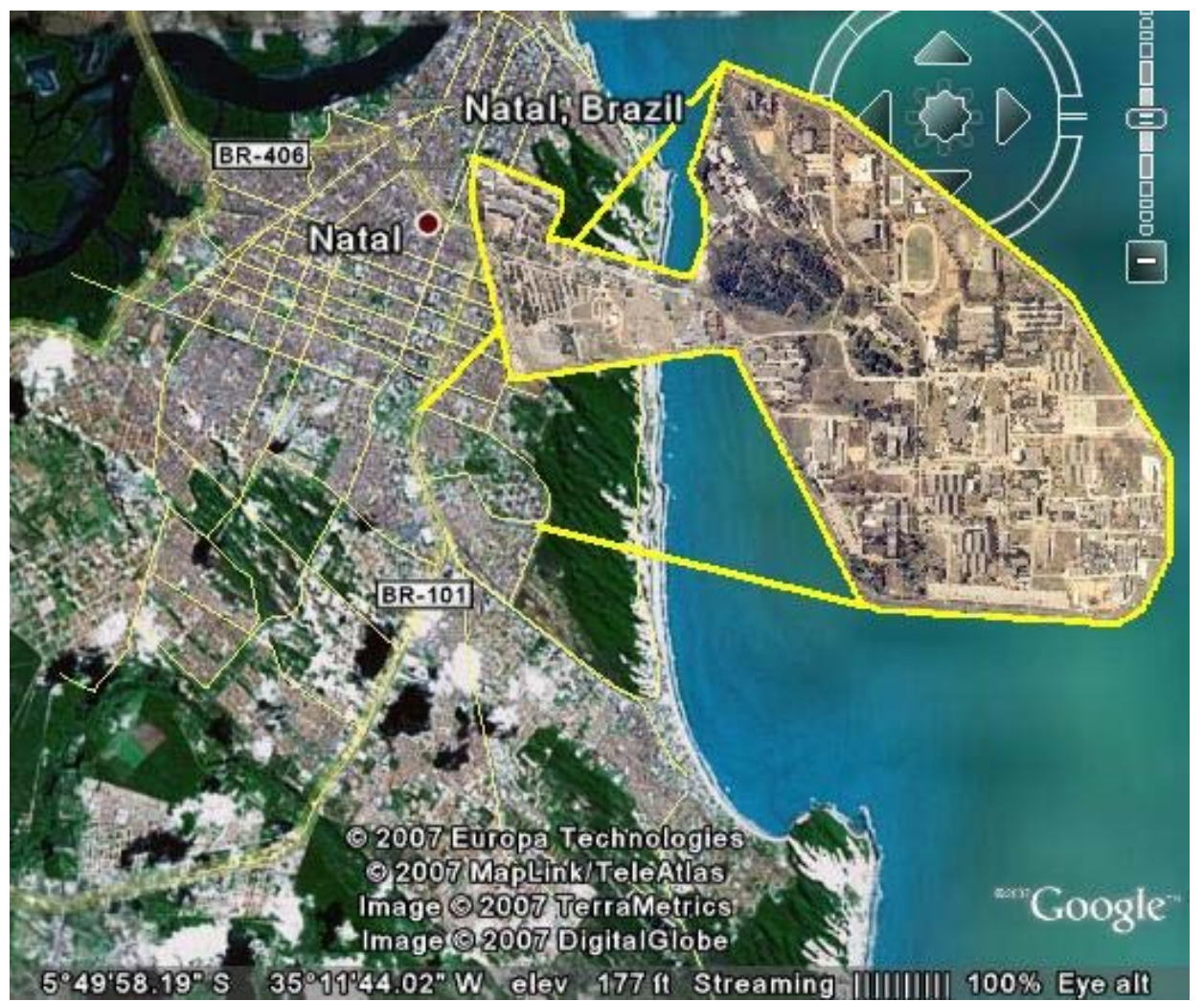

Figura 1 - Foto aérea de Natal, Campus Universitário da UFRN em destaque.

Fontes adaptadas: Google Earth Inc. e Departamento de memória da Superintendência da UFRN

Apesar da proximidade com o grande remanescente de mata atlântica do Parque das Dunas, o Campus da UFRN sofre com o calor generalizado e o empobrecimento paisagístico, os quais são provocados pela escassez de árvores (MASCARO e MASCARÓ, 
2002). O Campus possui 123 hectares e, anteriormente à implantação do PNC, continha somente 3.733 árvores, valor este que corresponde ao índice de 1 árvore para cada 333,3 $\mathrm{m}^{2}$ ou 1 árvore para aproximadamente 10 indivíduos da UFRN (CESTARO, 2005). Este índice, se comparado ao recomendado pela ONU, de $12 \mathrm{~m}^{2}$ de área verde por habitante de região urbana, indica que a situação está bem aquém do ideal.

Na Figura 2 estão demarcadas as áreas onde foram desenvolvidas as atividades no Campus Universitário da UFRN. Todas as quatro áreas - Florestinha dos Primatas; Bioparque; Avenida do RU; e Área verde do Centro de Convivência - possuíam um pobre aspecto paisagístico e baixo porte arbóreo. A quinta atividade foi desenvolvida no terreno da Escola Municipal Professora Francisca Ferreira de Souza, localizada no bairro Bom Pastor em Natal-RN.

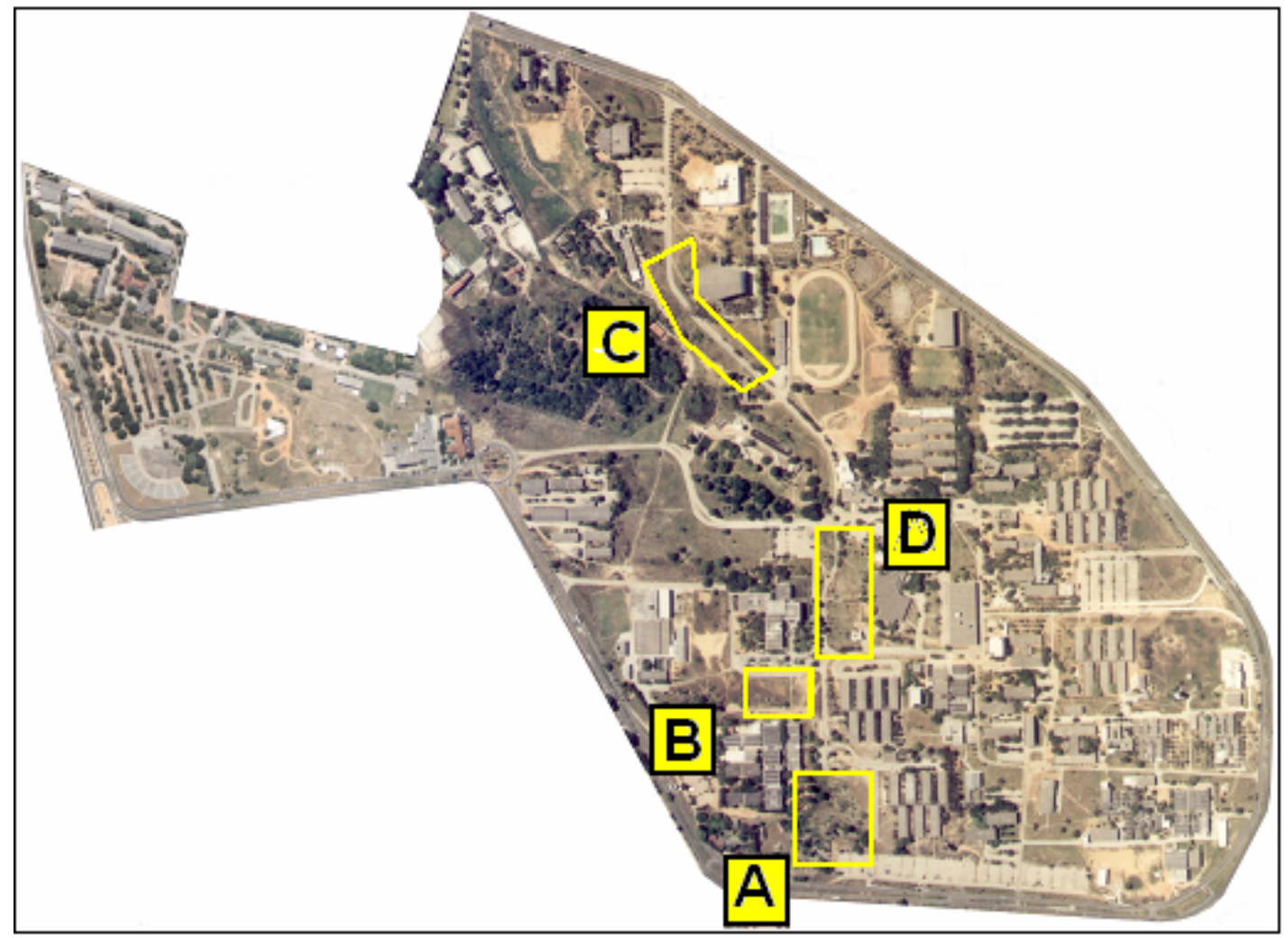

Figura 2 - Campus Universitário UFRN, áreas das atividades demarcadas. A Florestinha dos Primatas; B - Bioparque; C - Avenida do RU; D - Área verde do Centro de Convivência.

Fonte adaptada: Departamento de memória da Superintendência da UFRN.

\subsection{Plantio}

Segundo Cestaro (2005), o plantio é a ação de cultivar uma planta diretamente no solo, através de sementes (semear) ou mudas. O crescimento e desenvolvimento saudável de uma muda depende de alguns fatores, sendo o momento do plantio, provavelmente, o mais importante. Um dos objetivos da etapa é despertar no estudante a vontade de plantar árvores e fazê-lo assimilar a técnica de forma correta, e ainda, efetuar o plantio e manutenção da árvore. Por isso, é indispensável que o estudante receba orientação adequada. 
No momento do plantio, algumas regras devem ser respeitadas, visto que o seu sucesso está ligado tanto às condições de luz, umidade e solo, quanto à correta aplicação da técnica. Segundo Paiva e Gonçalves (2001, p. 5),

“(...) fatores como época do plantio, abertura de covas, adubação e tutoramento, também devem ser levados em consideração na hora do plantio, pois as árvores, quando bem plantadas, são mais respeitadas pela população e conseqüentemente, maiores são as suas chances de se desenvolverem e se tornarem adultas".

A metodologia seguida pelo PNC é embasada nos planos de arborização das cidades de Natal/RN (SECRETARIA ESPECIAL DE MEIO AMBIENTE E URBANISMO SEMURB, 2004), Porto Alegre/RS (SECRETARIA MUNICIPAL DO MEIO AMBIENTE - SMAM, 2000), São Paulo/SP (PREFEITURA DO MUNICÍPIO DE SÃO PAULO, 2004) e Vitória/ES (PREFEITURA MUNICIPAL DE VITÓRIA, 1992).

\subsection{Implantação das atividades de educação ambiental}

O modelo construído e seguido para realização das atividades de educação ambiental em questão envolve dois estágios, a programação e a efetivação ou implementação. A programação constitui a fase organizacional e preparatória da atividade. Consiste na elaboração e estabelecimento do plano de ação e trabalho a ser desenvolvido, abrangendo a escolha da atividade a ser realizada e seu agendamento, a seleção da escola ou instituição participante, o contato com os diretores e/ou professores responsáveis, o planejamento do translado dos estudantes, a confecção dos materiais a serem utilizados, a obtenção dos recursos necessários e a preparação da área onde será realizado o plantio. A efetivação representa a realização da atividade em si, sendo feita em 4 etapas seqüenciais: a recepção dos estudantes, exposição teórica de temas relacionados ao meio ambiente, arborização, e momento de interação. Em alguns momentos, houve a realização de uma atividade pósplantio, em dia posterior.

$\mathrm{Na}$ fase de implementação das atividades, houve sempre a busca por reunir duas modalidades de educação ambiental: formal e informal. A educação formal é aquela desenvolvida nas instituições de ensino clássicas - escolas e universidades, com conteúdos previamente demarcados (GOHN, 2006, p. 27) e implica o trabalho de conceitos ambientais aplicados em forma de conteúdo teórico. A educação informal é aquela que se aprende "no mundo da vida", via os processos de compartilhamento de experiências em espaços e ações coletivos cotidianas, englobando ações de grupos de jovens, movimentos juvenis, clubes, instituições esportivas e artísticas (GOHN, 2006, p.27) e envolve as atividades estendidas para fora do âmbito da sala de aula, visando à experimentação prática da teoria assimilada.

A recepção dos estudantes representa o primeiro contato dos coordenadores e demais realizadores da atividade com os mesmos, sendo fundamental para o êxito da atividade. Na chegada dos estudantes ao local, ocorre uma breve apresentação, geralmente em forma de dinâmica, entre os coordenadores responsáveis pela atividade e os estudantes. Na seqüência, se dá seguimento ao conteúdo programático teórico.

O segundo momento é a abordagem teórica, realizada através de palestras e algumas dinâmicas, como desenhos, questionários e jogos. Em síntese, procura-se ministrar as 
atividades de forma lúdica e pedagógica, com o objetivo de sensibilizar os estudantes e fazer com que estes participem ativamente das ações, percebendo-as, apreciando-as e valorizando-as. É importante ressaltar que a seqüência da abordagem teórica não necessariamente é a mesma em todas as atividades. Enquanto que em parte delas se realizavam as palestras em primeiro lugar e as dinâmicas posteriormente, houve atividades em que houve a confecção de desenhos (antes ou após as palestras) e a aplicação de dinâmicas ao início e término das palestras.

Essa etapa pretende mais que uma assimilação de conhecimentos ambientais por parte dos estudantes. Busca também o estímulo e a preparação destes para a efetivação do plantio. Uma preparação tanto no sentido de ensiná-los a importância de plantar e como fazer, quando no intento de criar um clima de bem-estar e harmonia para que haja um bom rendimento da atividade.

O conteúdo programático das intervenções foi ministrado pela sua divisão em quatro temáticas: a) importância do meio ambiente, b) bioma mata atlântica, c) homem e natureza, e d) importância da arborização. Essa divisão escolhida visa à organização didática das informações, permitindo momentos diferentes na exposição do conteúdo e participação de mais de um ministrante.

Ao fim desta etapa, segue-se uma explicação de como se plantar, a partir da metodologia utilizada pelo PNC. A conclusão da abordagem teórico-didática dá fim ao trabalho da educação ambiental formal e início do terceiro momento da implementação das atividades de educação ambiental, a realização da atividade de plantio em si.

Inicialmente, se reúne todos os participantes presentes na área onde é realizado o plantio e, mais especificamente, no local onde estiverem condicionados as mudas, ferramentas e recursos - barracas cedidas pelo exército. Nesta fase, ocorre um plantio explicativo feito por um coordenador (Figura 3). Essa demonstração de como se plantar serve de reforço ao entendimento da metodologia pelos estudantes. A seguir, ocorre o plantio das mudas feito pelos estudantes. 


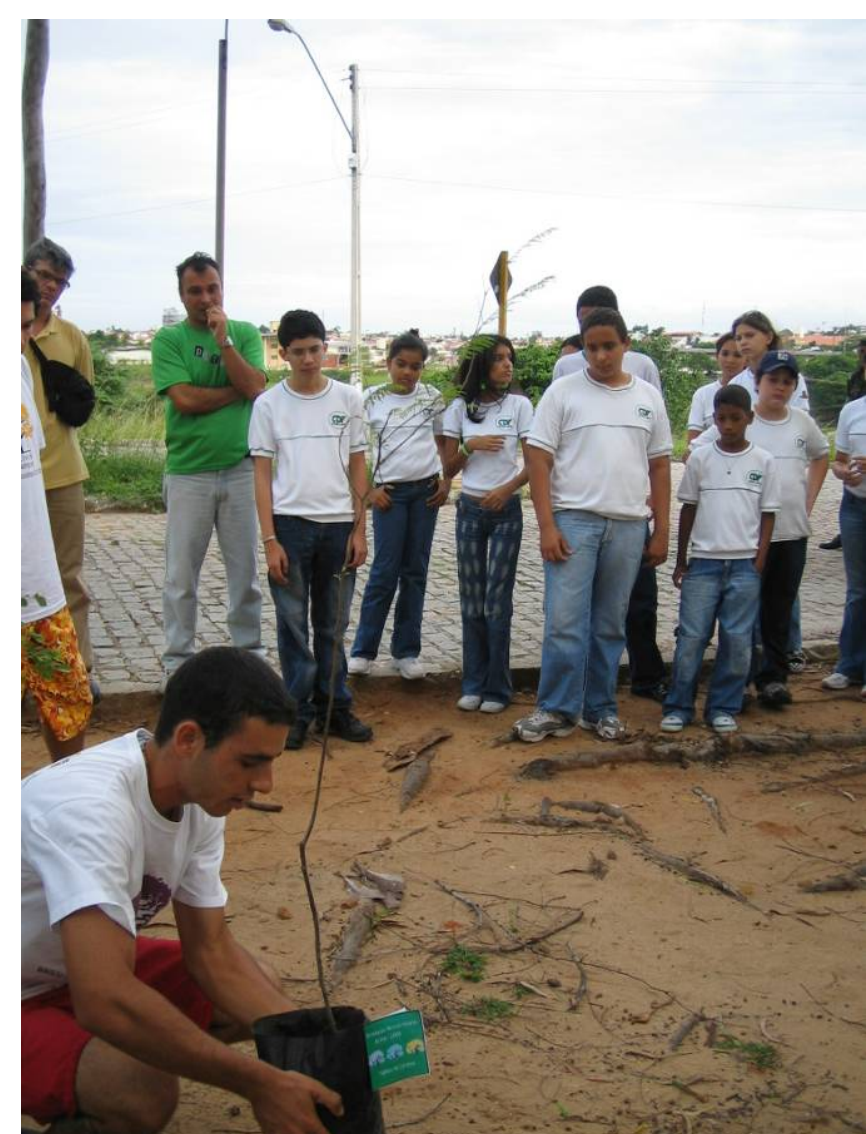

Figura 3 - Plantio explicativo realizado por coordenador - autor do artigo.

O plantio pode ocorrer de duas formas, a depender do número de estudantes participantes. Se a quantidade de estudantes participantes for superior a 15 , faz-se a divisão em grupos de 3 a 5 estudantes. Cada estudante ou grupo é acompanhado por um integrante do projeto, que orienta como se plantar e auxilia no plantio, sendo este realizado pelos estudantes. Dependendo da atividade, os estudantes ou grupos chegam a plantar um número elevado de mudas. Sempre que possível, junto à muda segue um folheto (Figura 4) contendo as informações dos nomes comum e científico da espécie, foto da árvore em seu estágio adulto, onde é encontrada, características e utilidades, entomofauna associada e curiosidades; e também alguma mensagem sobe a preservação da mata atlântica e sua importância. 


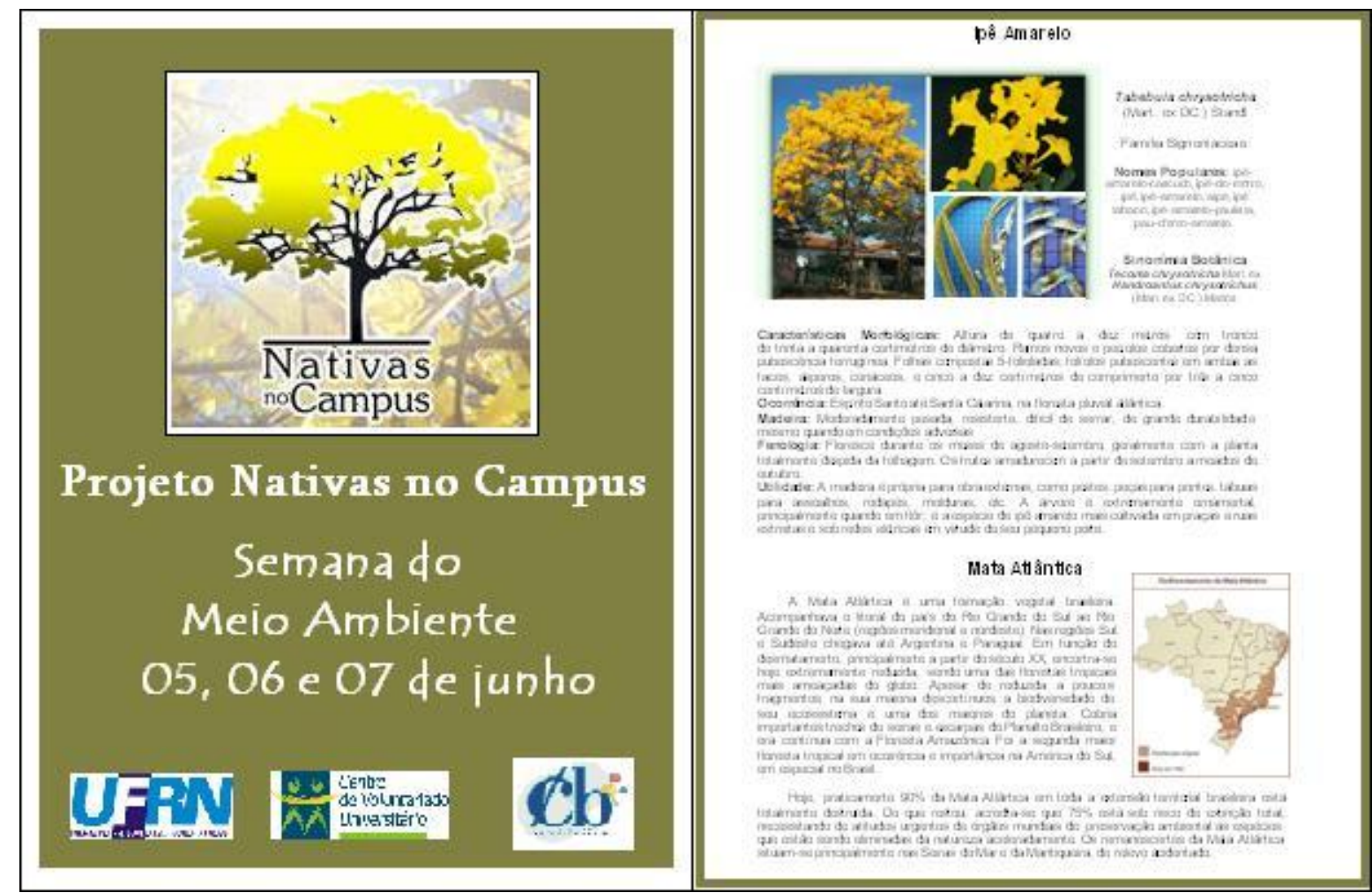

Figura 4 - Exemplo de folheto explicativo junto à muda (frente e verso).

Após plantadas todas as mudas, chega-se ao momento de interação, quando ocorre, basicamente, uma breve exposição temática sobre a responsabilidade com a muda plantada e o agradecimento a todos pela vinda e participação. A conclusão da atividade se dá com um breve discurso de agradecimento por parte dos coordenadores e translado dos estudantes de volta para a escola.

A etapa pós-plantio é efetivada, geralmente, com parte das turmas participantes das atividades e acontece através de visitações às escolas participantes, em um dia posterior à atividade que participaram. Consiste, principalmente, na execução de um novo desenho, por parte dos estudantes, acerca do mesmo tema 'O que é meio ambiente?'. Como preparação para o desenho, há um breve jogo de perguntas e respostas, com intuito de destacar, na memória dos estudantes, as lembranças das atividades executadas e conteúdo ministrado. O objetivo da etapa é a comparação entre os desenhos, para análise do conhecimento assimilado pelos estudantes.

\section{RESULTADOS E DISCUSSÕES}

Segundo os Parâmetros Curriculares Nacionais (2001), “(...) a principal função dos trabalhos com o tema meio ambiente é contribuir para a formação de cidadãos conscientes, aptos para decidirem e atuarem na realidade sócio-ambiental, de um modo comprometido com a vida e com o bem-estar de cada um e da sociedade." Os resultados almejados por este trabalho podem ser avaliados e estudados no intuito de se formular conclusões relativas à construção de uma consciência ambiental dos estudantes.

No período julho/2005 a julho/2006, foram realizadas cinco atividades de educação ambiental com estudantes. Foram contempladas as seguintes escolas: Escola Estadual Lauro de Castro, Escola Estadual Presidente Café Filho, Escola Estadual Floriano 
Cavalcanti, o Centro Educacional Santo Agostinho, CDF Colégio e Curso - Unidade Deodoro e Escola Municipal Professora Francisca Ferreira de Souza. Destas, as quatro primeiras foram realizadas no Campus Universitário da UFRN e a derradeira no terreno da Escola Municipal Professora Francisca Ferreira de Souza. A Escola Municipal Professora Francisca Ferreira de Souza e a Escola Estadual Floriano Cavalcanti participaram com duas turmas de duas séries diferentes e o CDF Colégio e Curso - Unidade Deodoro com quatro turmas de três séries diferentes.

No dia 02 de setembro de 2005, em comemoração ao dia do biólogo, o PNC realizou um grande evento de arborização, com plantio superior a 200 plantas. O local da realização foi a 'Florestinha dos Primatas' - área anexa ao Centro de Biociências da UFRN. A atividade de educação ambiental foi realizada pela manhã, sendo desenvolvida por três coordenadores do projeto e contando com a participação de uma turma do $5^{\circ}$ ano da Escola Estadual Lauro de Castro (Figuras 5 e 6).

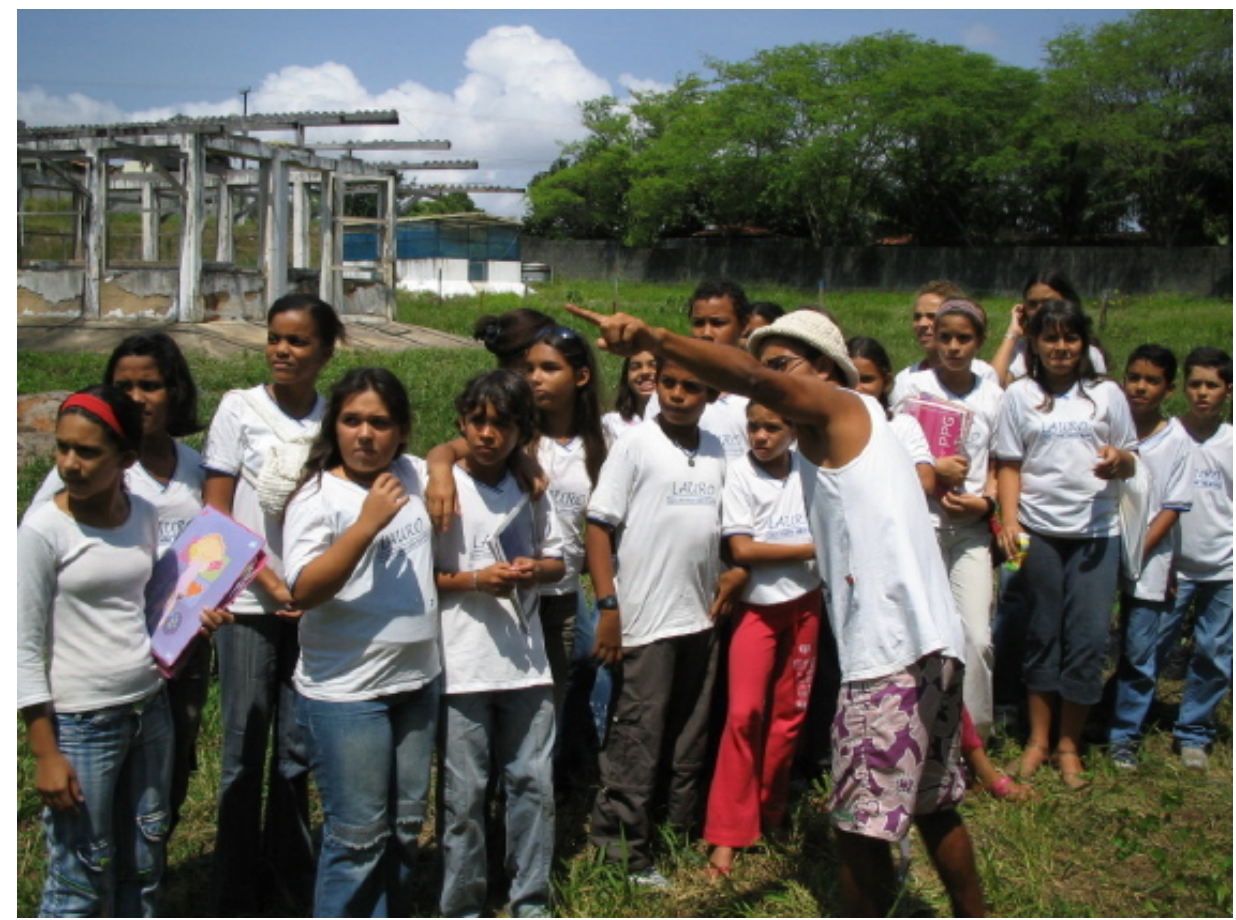

Figura 5 - Realização de trilha com estudantes. 


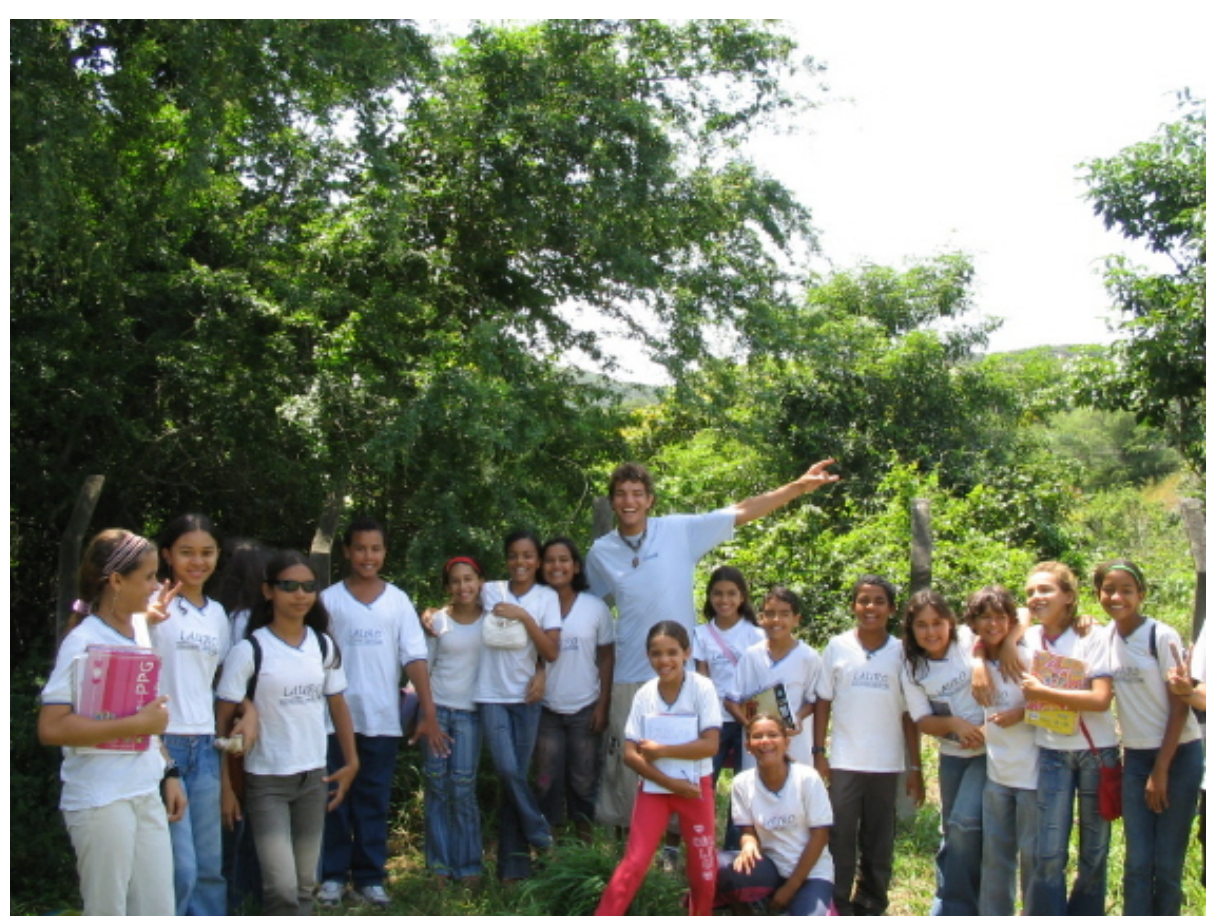

Figura 6 - Interação com estudantes ao fim da atividade.

No dia 19 de novembro de 2005, o PNC efetuou uma atividade de educação ambiental com duas turmas do $6^{\circ}$ ano da escola particular CDF Colégio e Curso- Unidade Deodoro (Figura 7). A atividade foi realizada no 'Bioparque' - área anexa ao Centro de Biociências da UFRN, sendo implementada pela equipe de educação ambiental do PNC, composta por seis integrantes.

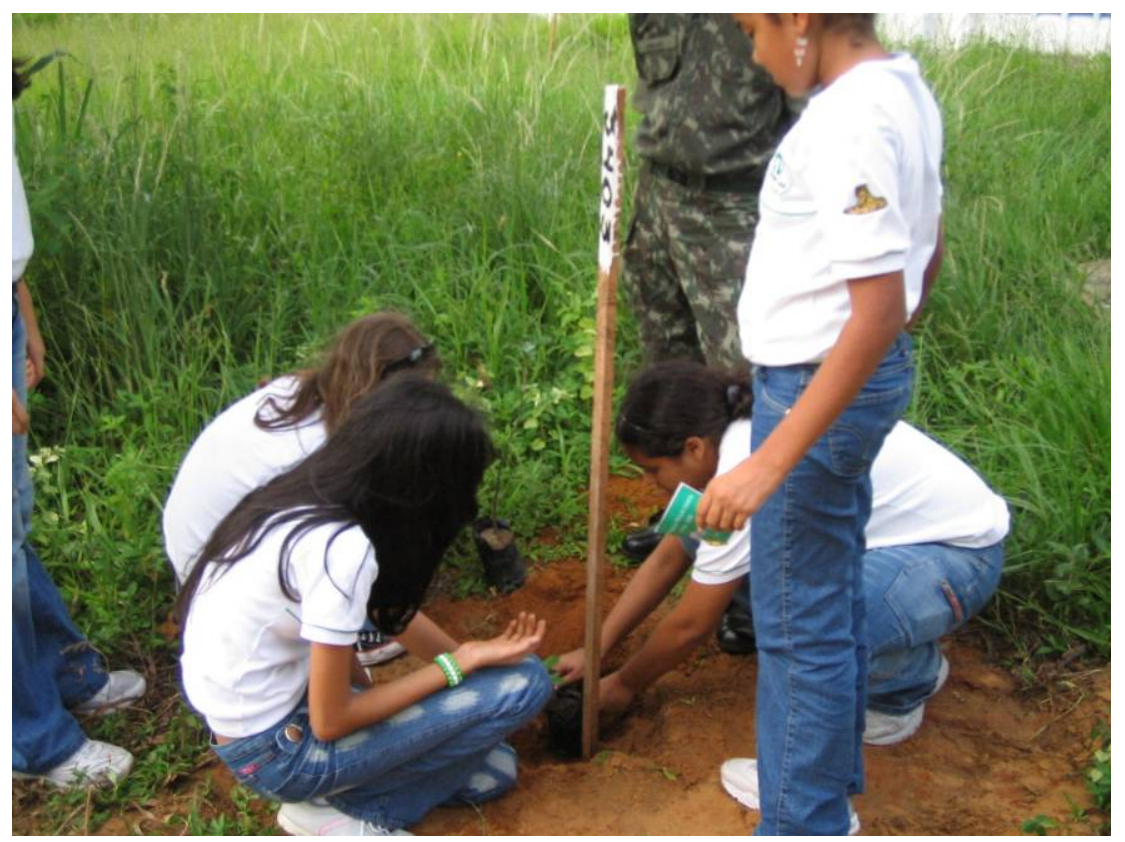

Figura 7 - Plantio de muda realizado por grupo de estudantes.

No dia 29 de novembro de 2005, o PNC realizou uma atividade contemplando duas turmas ( $8^{\circ}$ e $9^{\circ}$ ano) da Escola Estadual Professora Francisca Ferreira de Souza. A atividade foi 
dirigida por três coordenadores da equipe de educação ambiental e aconteceu na própria escola, a convite da mesma.

Em junho/2006 houve a participação de quatro escolas com atividades de educação ambiental, realizadas na Semana do Meio Ambiente, com um grande evento de arborização promovido pelo PNC, que contou com participação efetiva, em sua organização, do $7^{\circ}$ Batalhão de Engenharia e Combate do Exército - Becomb. As escolas participantes foram as seguintes: Escola Estadual Presidente Café Filho - turma do $4^{\circ}$ ano (Figura 8), o Centro Educacional Santo Agostinho - turma do $7^{\circ}$ ano (Figura 9), a Escola Estadual Floriano Cavalcanti - $8^{\circ}$ e $9^{\circ}$ ano (Figura 10) e o CDF Colégio e Curso - Unidade Deodoro - turmas do $7^{\circ}$ ano (Figura 11).

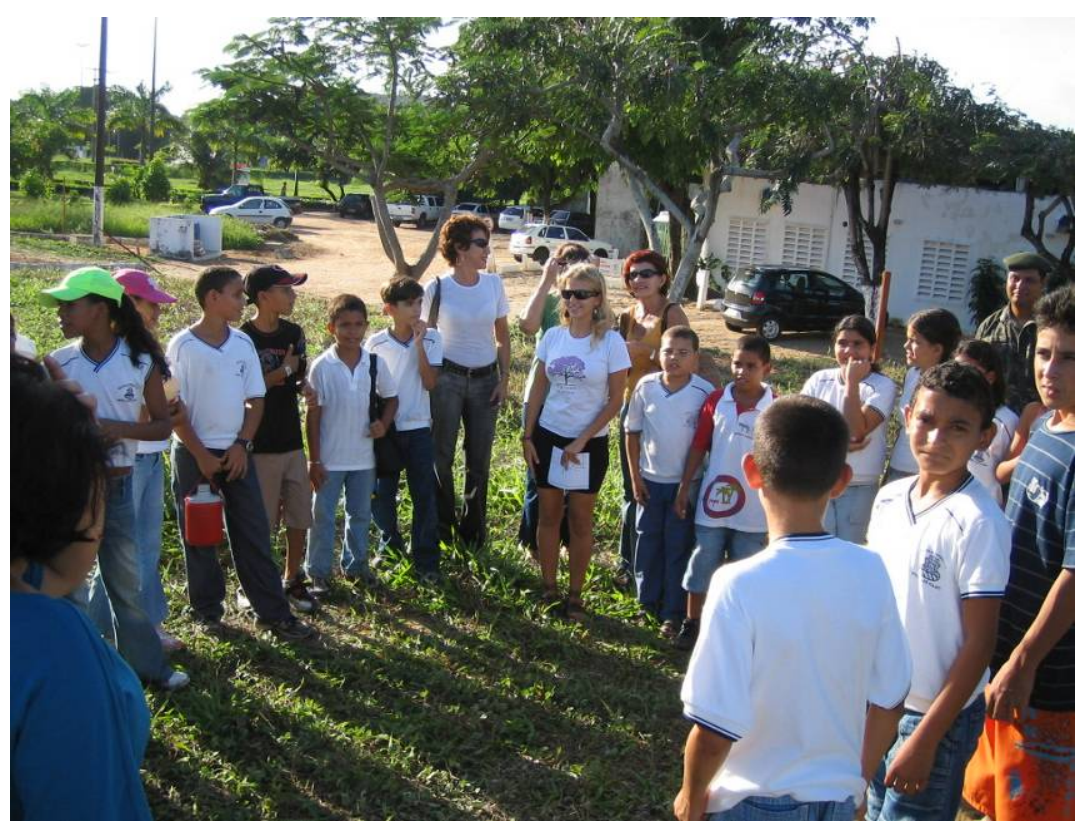

Figura 8 - Estudantes da Escola Estadual Presidente Café Filho.

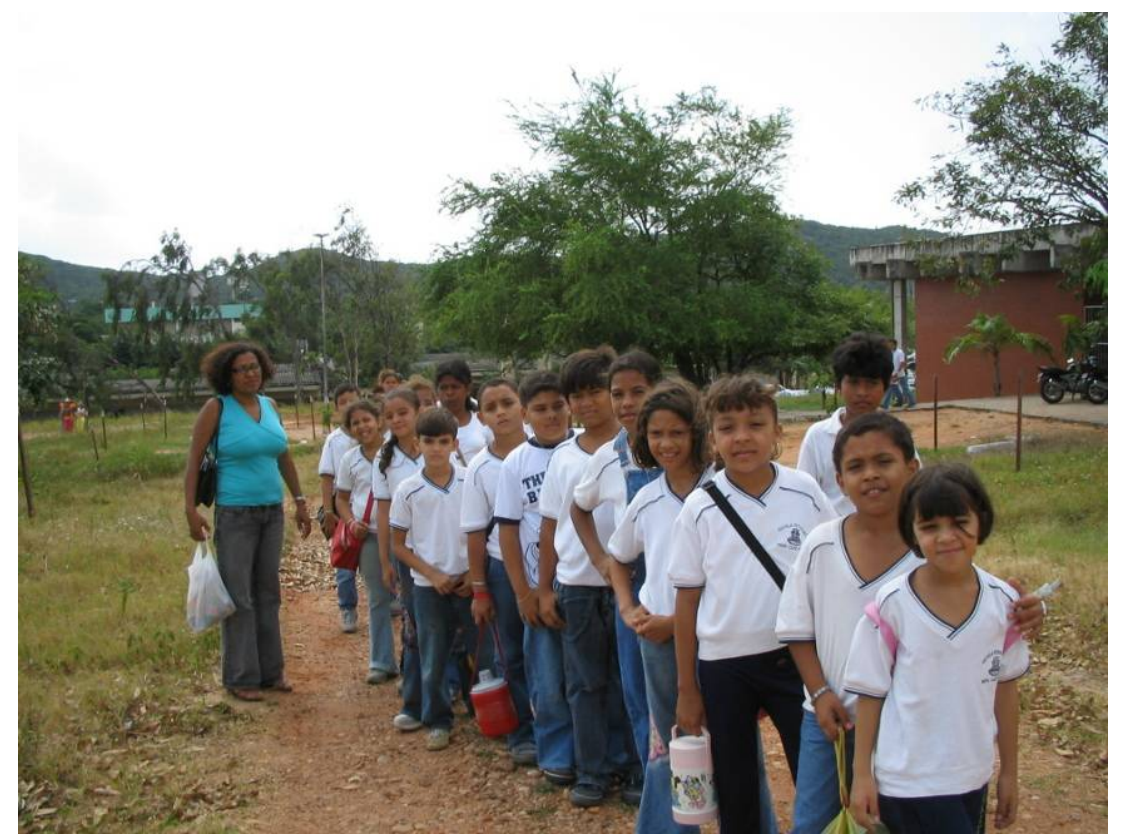

Figura 9 - Estudantes do Centro Educacional Santo Agostinho. 


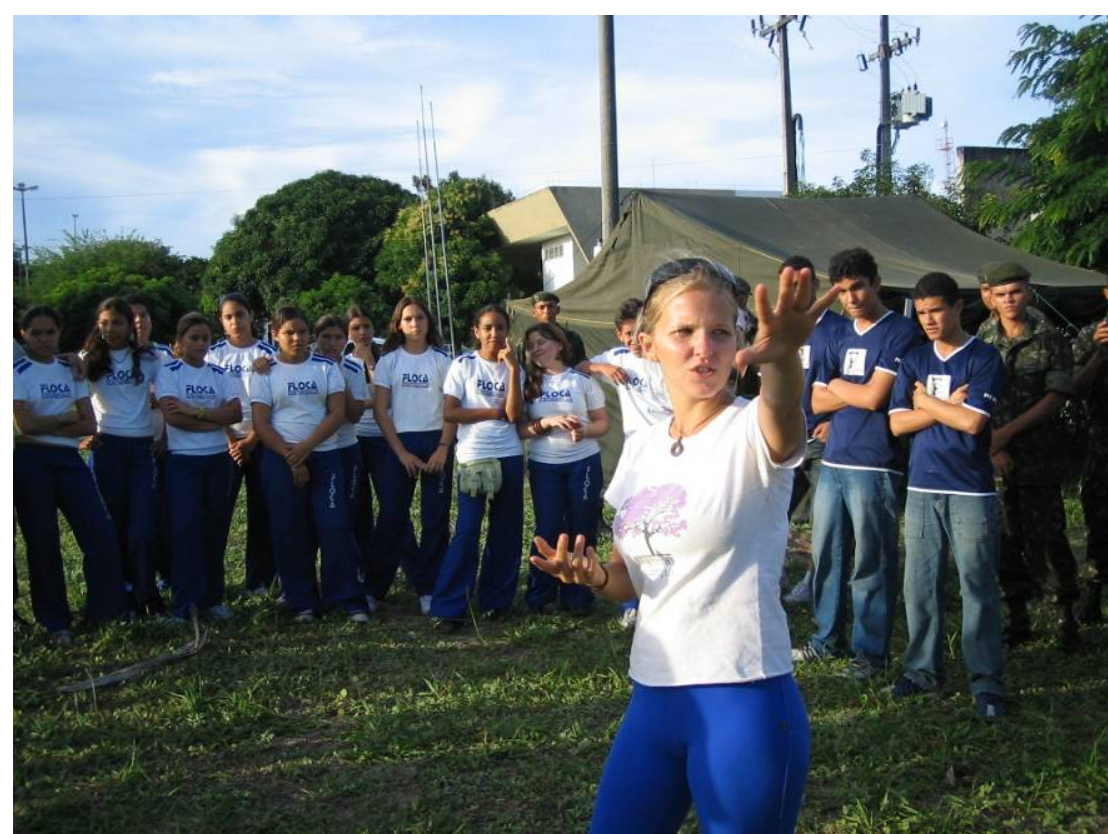

Figura 10 - Estudantes da Escola Estadual Floriano Cavalcanti.

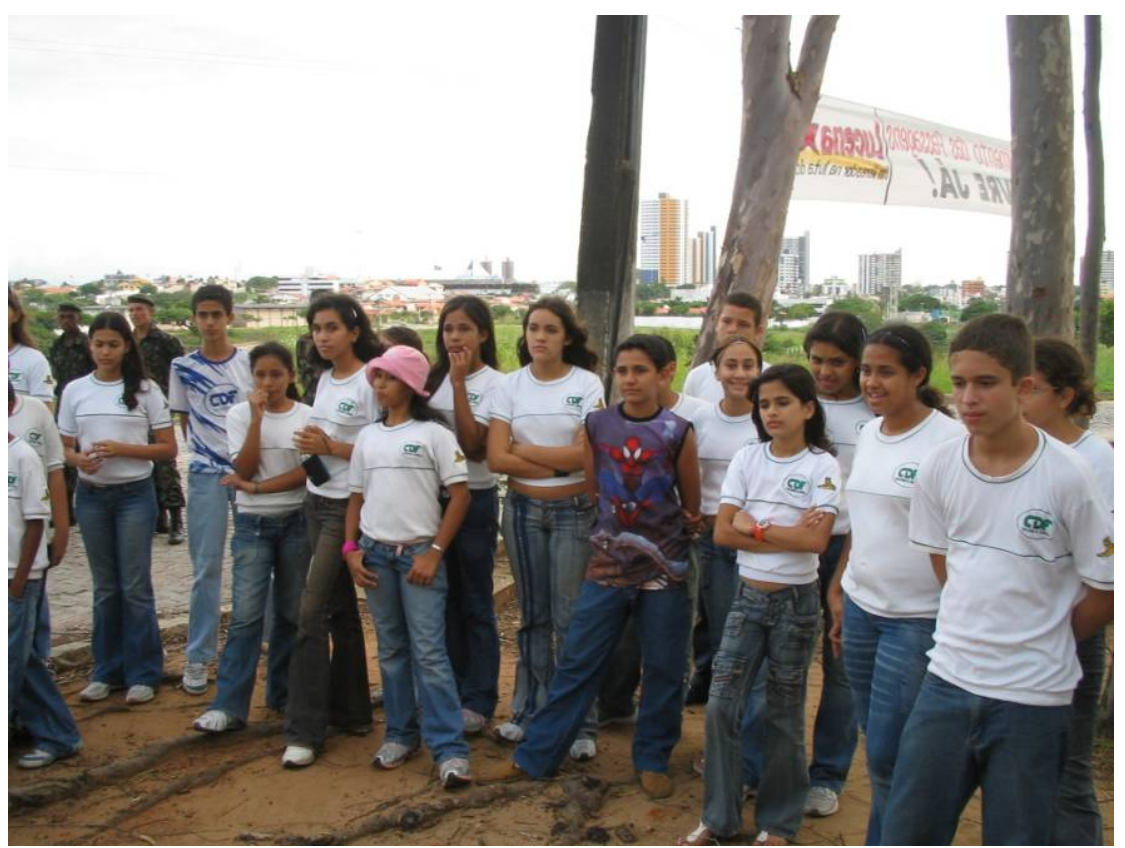

Figura 11 - Estudantes do CDF Colégio e Curso - Unidade Deodoro.

Nos dias 02, 05 e 06 de junho/2006 foram ministradas palestras para os estudantes das escolas citadas anteriormente, em suas próprias salas de aula. Juntamente com as palestras, foi requisitada aos estudantes a atividade de produção de um desenho sobre Meioambiente. No Centro Educacional Santo Agostinho e no CDF Colégio e Curso - Unidade Deodoro, os desenhos foram feitos anteriormente às palestras. Na Escola Estadual Presidente Café Filho, tal exercício ocorreu após as palestras concluídas. Nas turmas da Escola Estadual Floriano Cavalcanti não houve a confecção dos desenhos.

Seqüencialmente, desenvolveu-se a atividade de arborização. As turmas da Escola Estadual Presidente Café Filho e do Centro Educacional Santo Agostinho participaram do evento no dia 07 de junho/2006, enquanto as da Escola Estadual Floriano Cavalcanti e do CDF 
Colégio e Curso - Unidade Deodoro participaram no dia 08 de junho/2006. O PNC responsabilizou-se por toda atividade desenvolvida, inclusive pelo transporte dos estudantes.

Nos dias dos plantios, foram ministradas breves palestras nos locais das atividades visando retomar os temas abordados nas salas de aula. O plantio foi realizado com a sistemática de grupos com 3 a 5 estudantes acompanhados de um coordenador e/ou soldado - Figuras 12, 13 e 14.

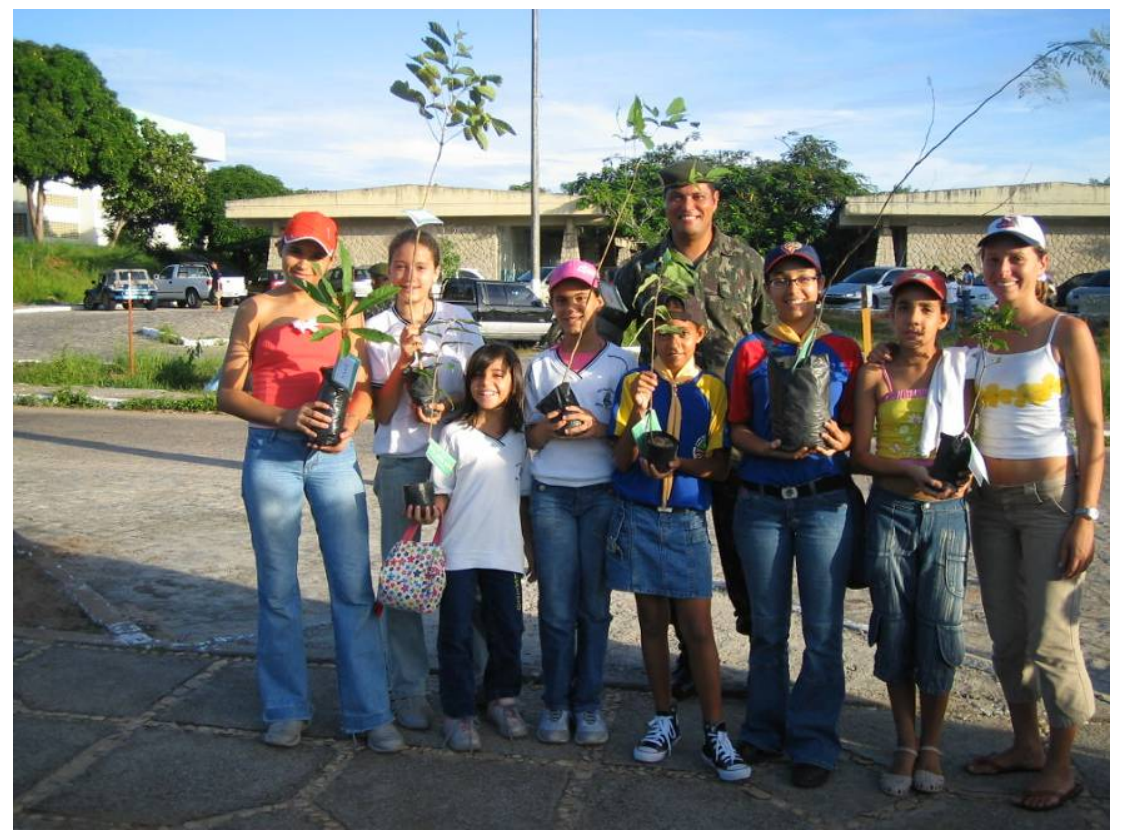

Figura 12 - Estudantes e coordenadores em momento anterior ao plantio.

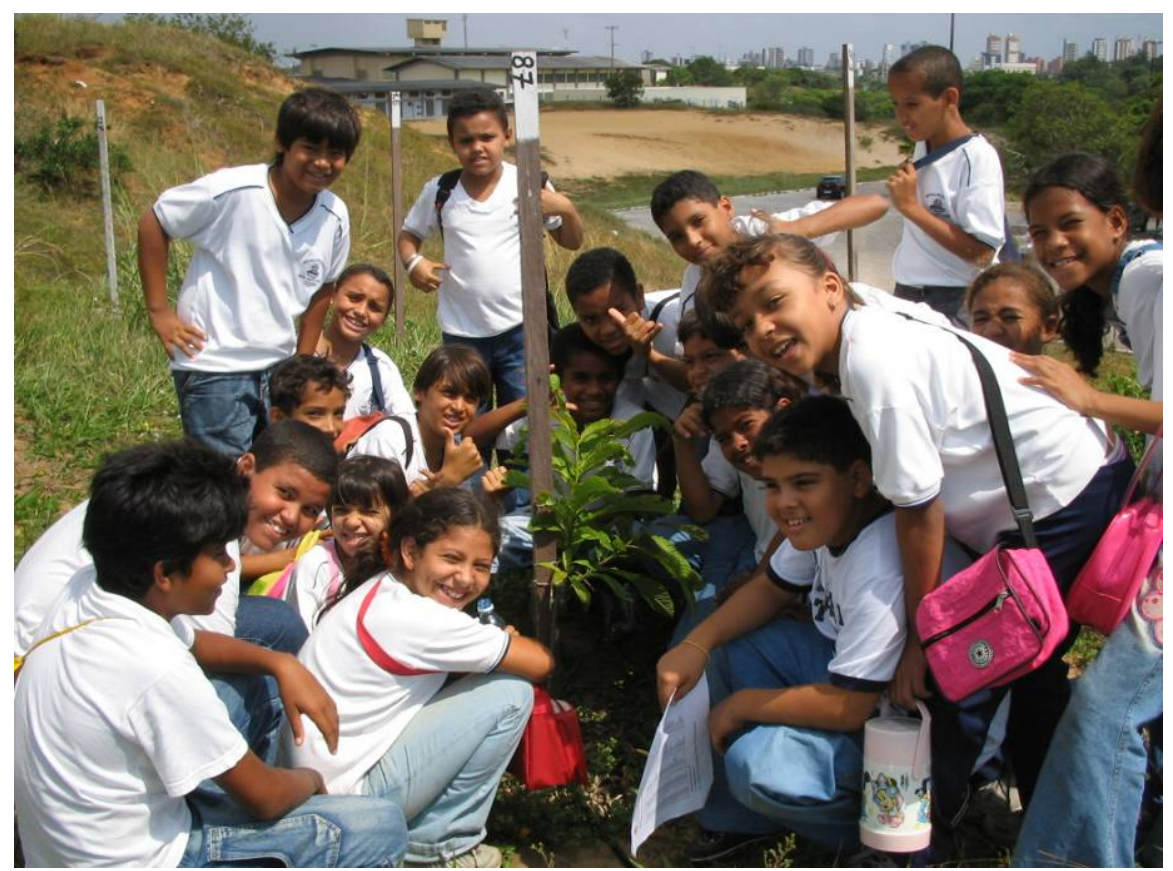

Figura 13 - Plantio realizado pelos estudantes da Escola Estadual Presidente Café Filho. 


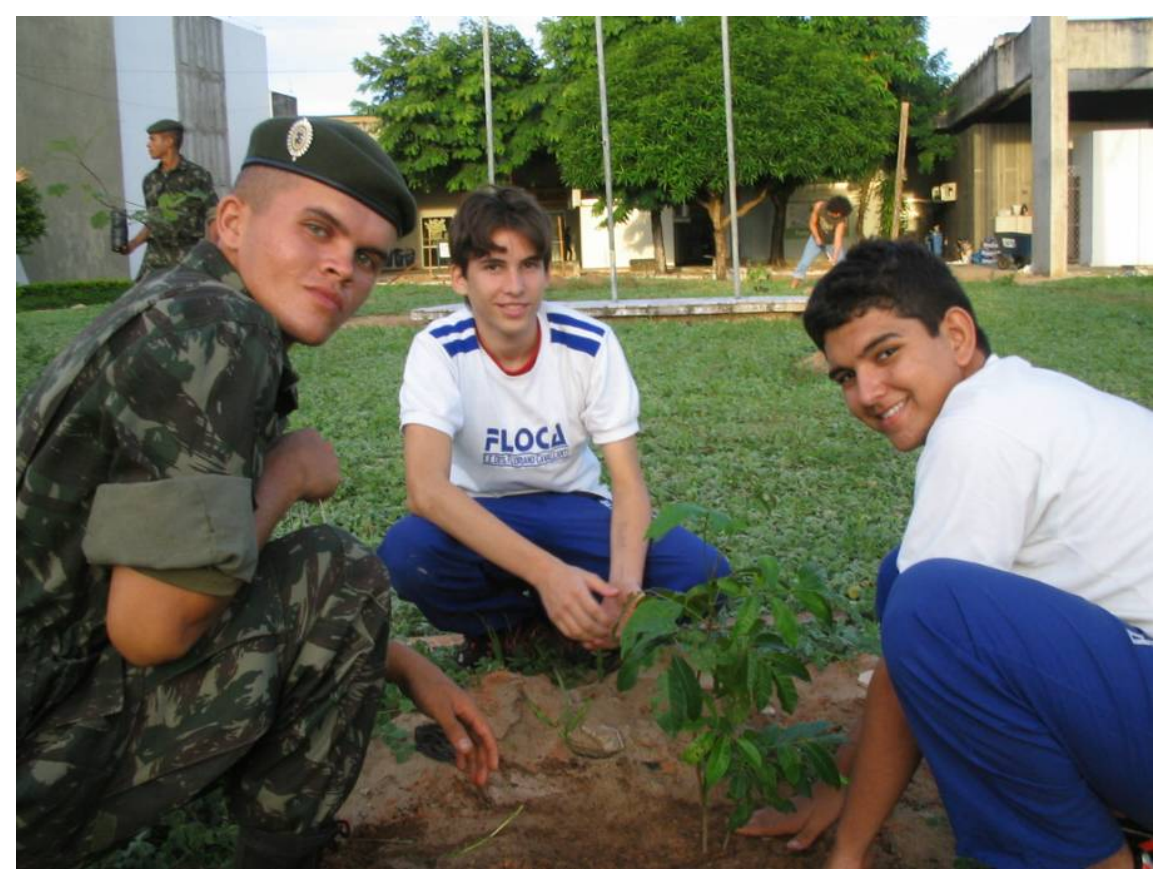

Figura 14 - Plantio realizado por estudantes da Escola Estadual Floriano Cavalcanti.

Ao término as atividades foram desenvolvidas brincadeiras educativas, envolvendo jogos de perguntas e respostas, e o momento de interação. Ao final de todas as atividades, o PNC e seus participantes agradeciam a todos pela vinda e participação. Da mesma forma, em todas as atividades os responsáveis pelos estudantes agradeceram o convite e realização da atividade.

No mês de setembro/2006, houve retorno às escolas e desenvolvimento de uma nova atividade de desenho, novamente acerca do tema Meio-ambiente. Foram realizadas nos dias 07 (Centro Educacional Santo Agostinho), dia 11 (Escola Estadual Presidente Café Filho) e dia 14 (CDF Colégio e Curso - Unidade Deodoro). O objetivo foi comparar os desenhos realizados anteriormente à atividade com aqueles feitos posteriormente.

Os primeiros resultados podem ser registrados já no momento de recepção dos estudantes. Os estudantes, em maioria, chegam muitas vezes ávidos e despreparados para o trabalho, e apesar de, geralmente, chegarem em estado de excitação, se constata uma timidez nos primeiros contatos. A realização da apresentação de todos os envolvidos, através de dinâmicas, atinge satisfatoriamente o objetivo da etapa de se criar um clima harmonioso e dar predisposição aos estudantes para a execução adequada da atividade. Ressalta-se que as experiências de Feuerstein, relatadas em Carvalho (2005, p. 28), detectaram uma predisposição diferenciada para aprendizagem pelos estudantes, quando trabalhado, em relevância, o aspecto da recepção em atividades objetivas através do entretenimento.

A modificação na rotina da escola faculta aos estudantes uma afloração da memória e melhor registro dos acontecimentos. O deslocamento permitido pela atividade extra-classe os torna mais alertas e dispostos, aumentando a percepção e facilitando a absorção dos aprendizados. Acredita-se que a atividade prática é essencial na construção da educação ambiental em cada um. Philippi e Pelicioni (2005, p. 178) afirma que "Consciência 
ecológica sem ação transformadora ajuda a manter a sociedade tal qual ela se encontra.” A consciência "deve ocorrer de forma agradável, nunca de maneira impositiva ou monótona" (MERGULHÃO e VASAKI, 2002). Mesmo sem haver uma percepção clara por parte deles, inicia-se a harmonização com o ambiente novo em que se encontram, por meio dos sentidos de cada um e das palestras e exercícios de apresentação realizados. Assim, a recepção dos estudantes visa fazer do primeiro contato um momento positivo de descontração e preparação.

Quanto ao trabalho da educação ambiental formal, realizado através da abordagem teórica por meio de palestras e dinâmicas, crê-se que a maioria dos resultados auferidos nesta etapa não são imediatos, no entanto, alguns o são e se fazem bastante perceptíveis. Faz-se claramente notável as mudanças de expressões dos estudantes no decorrer das palestras. Acredita-se que tal processo se manifeste pela forma lúdica de trabalhar, envolvendo a participação coletiva por meio de perguntas e jogos. Segundo Mendonça (In: SERRANO, 2000, p. 135), o professor Joseph Cornell abordou este processo de transformação para receptividade pelo conceito de afetividade. Logicamente esse processo ocorre heterogeneamente entre turmas, estudantes e conforme a temática abordada.

Berna (2001) explicitou que:

Defender a natureza, a flora, o meio ambiente, a ecologia, preservar os ecossistemas e os habitats, combater a depredação dos recursos naturais, a poluição dos mananciais (...), são palavras e conceitos que se tornaram comuns hoje em dia.

Entretanto, presume-se que, em relação aos estudantes do ensino fundamental, o percentual destes conceitos já conhecidos seja baixo e que o despertar de interesse acontece justamente por estarem eles tendo acesso a um conteúdo novo. Acredita-se que grande parte das informações repassadas aos estudantes são parcial ou totalmente desconhecidas. Isso acontece em razão de um trabalho de educação ambiental pouco desenvolvido nas escolas de ensino fundamental e moderada divulgação dos recursos naturais municipais e estaduais por parte dos órgãos e instituições responsáveis.

O exposto acima pode ser exemplificado por questionamentos básicos feitos em relação ao conteúdo de embasamento das palestras. Na exposição da temática Bioma da mata atlântica, por exemplo, percebeu-se que apesar de ser o bioma mais próximo (geograficamente) do meio onde estão inseridos, pouco conheciam sobre o mesmo. Constatou-se que somente $10 \%$ dos estudantes acertaram todas as perguntas e $65 \%$ acertou menos da metade, somando-se os questionários aplicados em todas as atividades.

Contudo, este baixo percentual de conhecimento prévio, acerca dos conceitos e conteúdo ambiental, ocasiona um efeito bastante proveitoso, o despertar e atenção para o conhecimento transmitido (CHAPANI e DAIBEM, In: TALAMONI, 2003, p. 21). Em praticamente todas as atividades desenvolvidas, percebeu-se notável atenção por parte dos estudantes às palestras ministradas. Acredita-se que tal fato se deva a dois fatores. Primeiramente, pelo fato de a atividade ser realizada de uma forma inovadora e, por isso, o estímulo favoreceu o despertar do aprendizado. Em segundo lugar, pela forma de exposição do conteúdo envolvendo dinâmicas com jogos e perguntas.

Em relação aos jogos propostos em sala de aula, as Orientações Curriculares para o Ensino Médio (BRASIL, 2006, p. 28) afirmam que tal prática: 
“(...) oferece o estímulo e o ambiente propícios que favorecem o desenvolvimento espontâneo e criativo dos estudantes e permite ao professor ampliar seu conhecimento, (...) mostrando-lhes uma nova maneira, lúdica, prazerosa e participativa de relacionar-se com o conteúdo escolar, levando a uma maior apropriação dos conhecimentos envolvidos.”

Assim, ao se fazer um exercício lúdico na forma de dinâmicas, consegue-se a atenção e consonância dos estudantes. Concomitantemente, os executores principiam a conhecer a turma com quem vão trabalhar e se harmonizar igualmente.

A confecção dos desenhos, sobre o tema 'O que é meio ambiente?', foi realizada somente nas atividades realizadas na semana do meio ambiente de 2006. As turmas participantes foram o $4^{\circ}$ ano da Escola Estadual Presidente Café Filho (Café Filho), o $7^{\circ}$ ano do Centro Educacional Santo Agustinho (CESA) e o $7^{\circ}$ ano do CDF Colégio e Curso - Unidade Deodoro (CDF). Conforme descrito no item Metodologia, foram confeccionados desenhos antes e depois das atividades de plantio. Quanto à primeira fase dos desenhos, nas escolas CESA e CDF a aplicação se deu anteriormente a execução das palestras e, apenas na turma da escola Café Filho, os desenhos foram feitos em seguida a efetivação das palestras. Para apresentação dos desenhos como resultados, os mesmos foram divididos em três categorias: 1 - Presença apenas de elementos da natureza, fauna e flora (Figura 15);

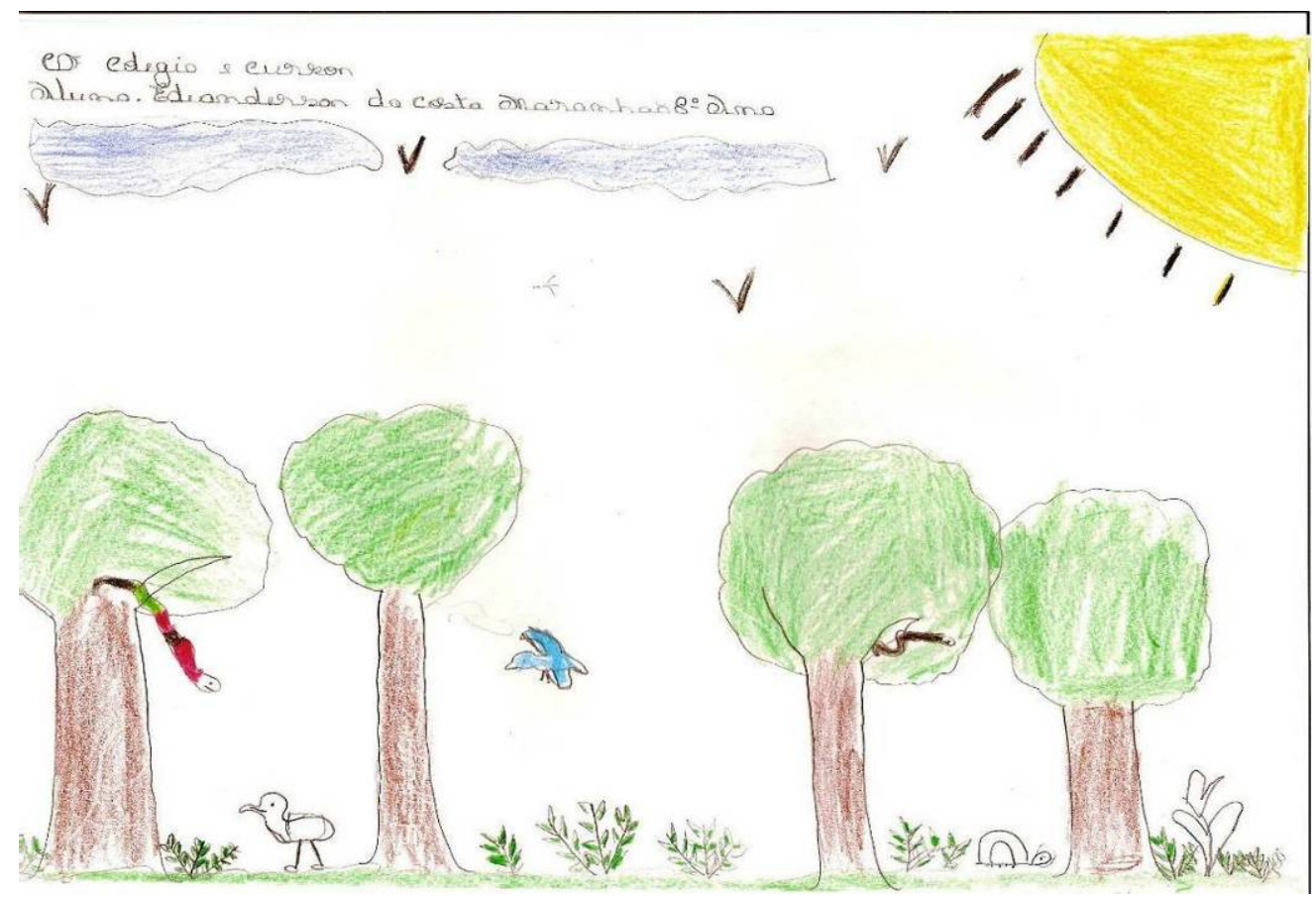

Figura 15 - Desenho representando a Categoria 1 - somente elementos da fauna e flora.

2 - Presença de algum elemento antrópico - casa, avião, barco (Figura 16); 


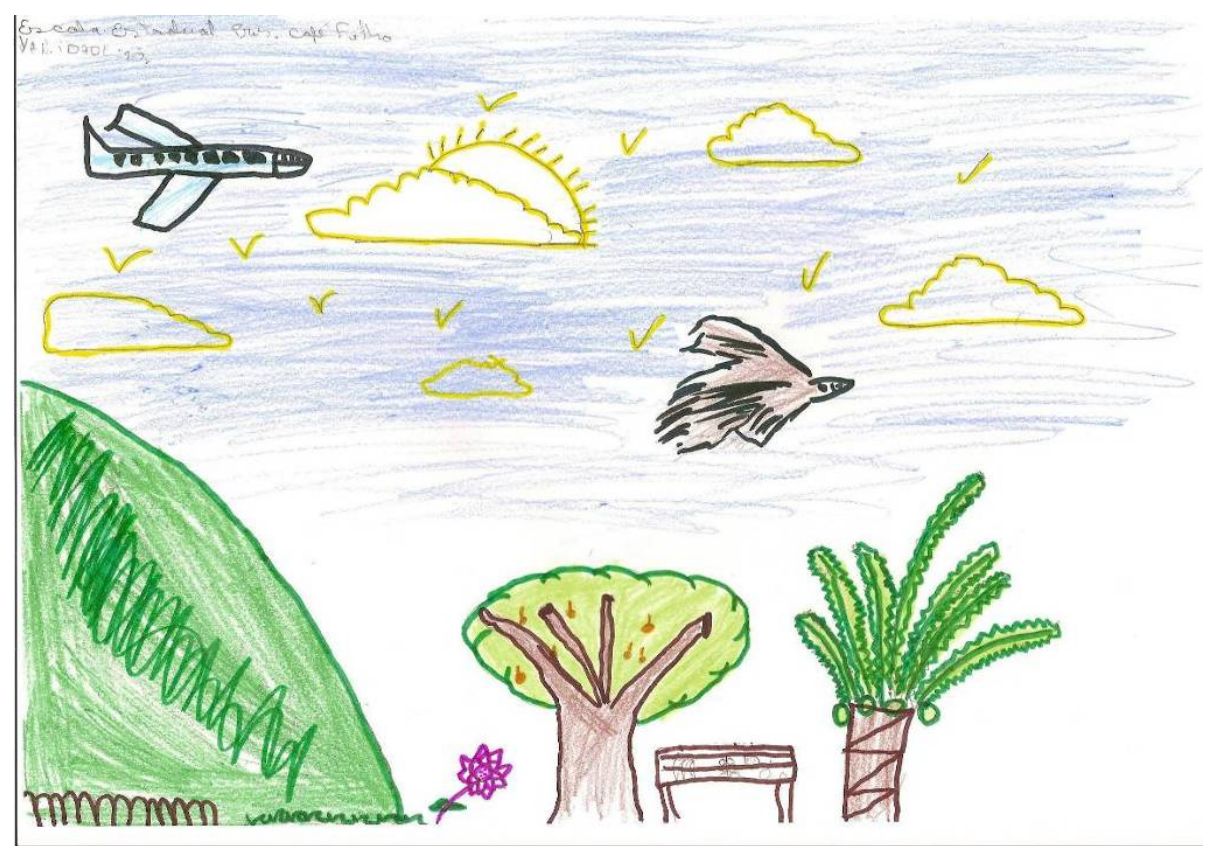

Figura 16 - Desenho representando a Categoria 2 - presença de algum elemento antrópico.

3 - Presença de homens ou elementos antrópicos ligados ao meio ambiente - árvore cortada, fogo, lixeiros, sede do IBAMA, motoserra, etc (Figura 17).
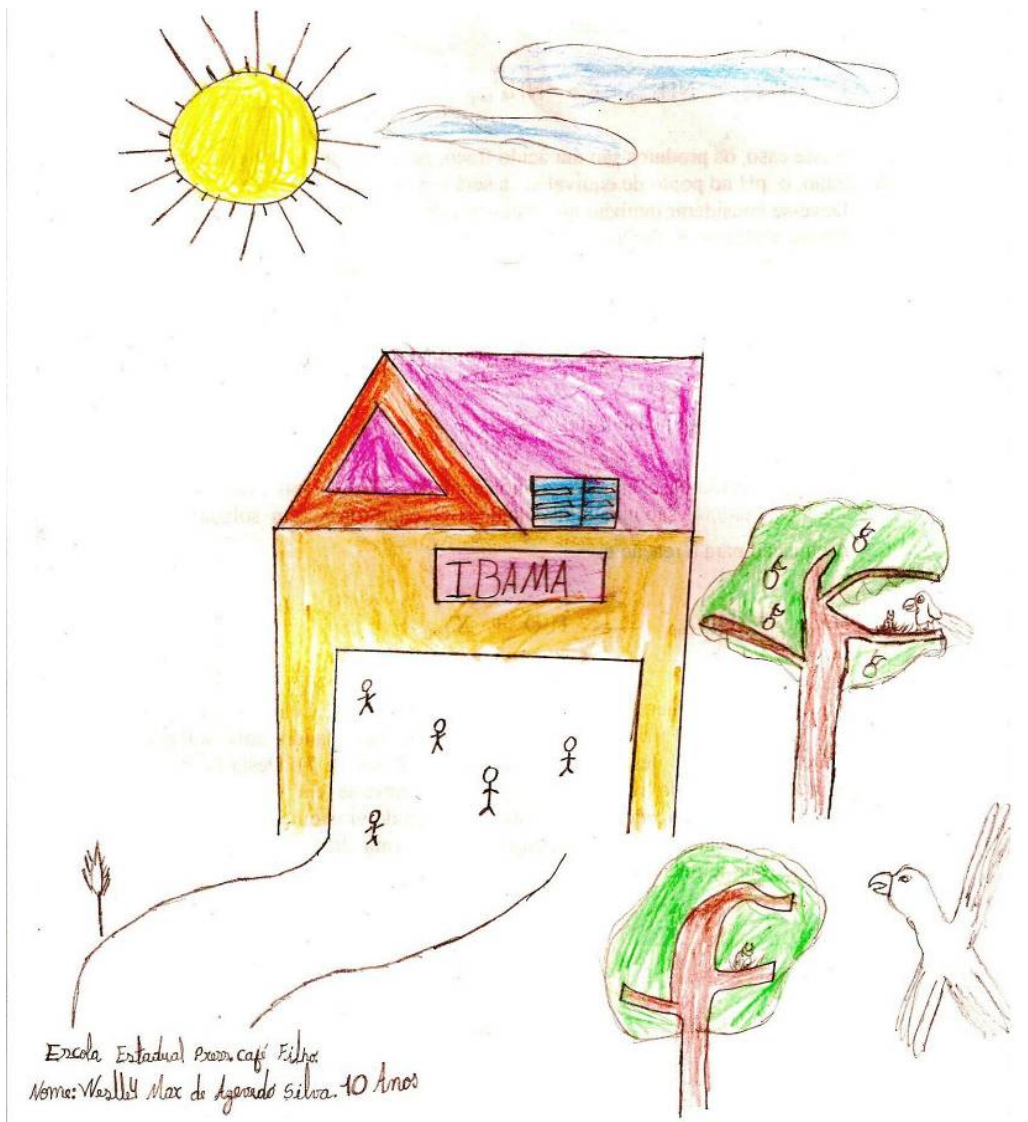

Figura 17 - Desenho representando a Categoria 3 - presença de algum elemento antrópico ligado ao meio ambiente. 
O total de desenhos foi de 178, dos quais a maioria se enquadra na Categoria 1. Em termos absolutos, 104 desenhos somente apresentaram elementos naturais, da fauna e flora, o que em valores percentuais representa $58,4 \%$ do todo. Esse dado, isolado, demonstra, preliminarmente, que a concepção de ambiente da maioria dos estudantes é restrita a bichos, plantas, lixo, tendo como referência a utilidade imediata da natureza para o ser humano. "Esta visão antropocêntrica tem sido reforçada na educação tradicional, onde somente há transmissão de conhecimentos, que na maior parte das vezes apresentam-se desvinculados da realidade” (GRUN, 1996 apud REIGADA 2004).

Os gráfico a seguir (Figura 18) demonstra os valores percentuais dos desenhos por categoria, os quais podem incrementar a avaliação. A diferença existente entre o número de desenhos apurados antes e depois da atividade deve-se somente ao não comparecimento de todos os estudantes na atividade ou sala de aula. Isto porque todos os estudantes que estavam presentes na fase de confecção dos desenhos, participaram desta atividade. Ressalta-se que eles foram deixados à vontade para decidirem por fazer ou não os desenhos.
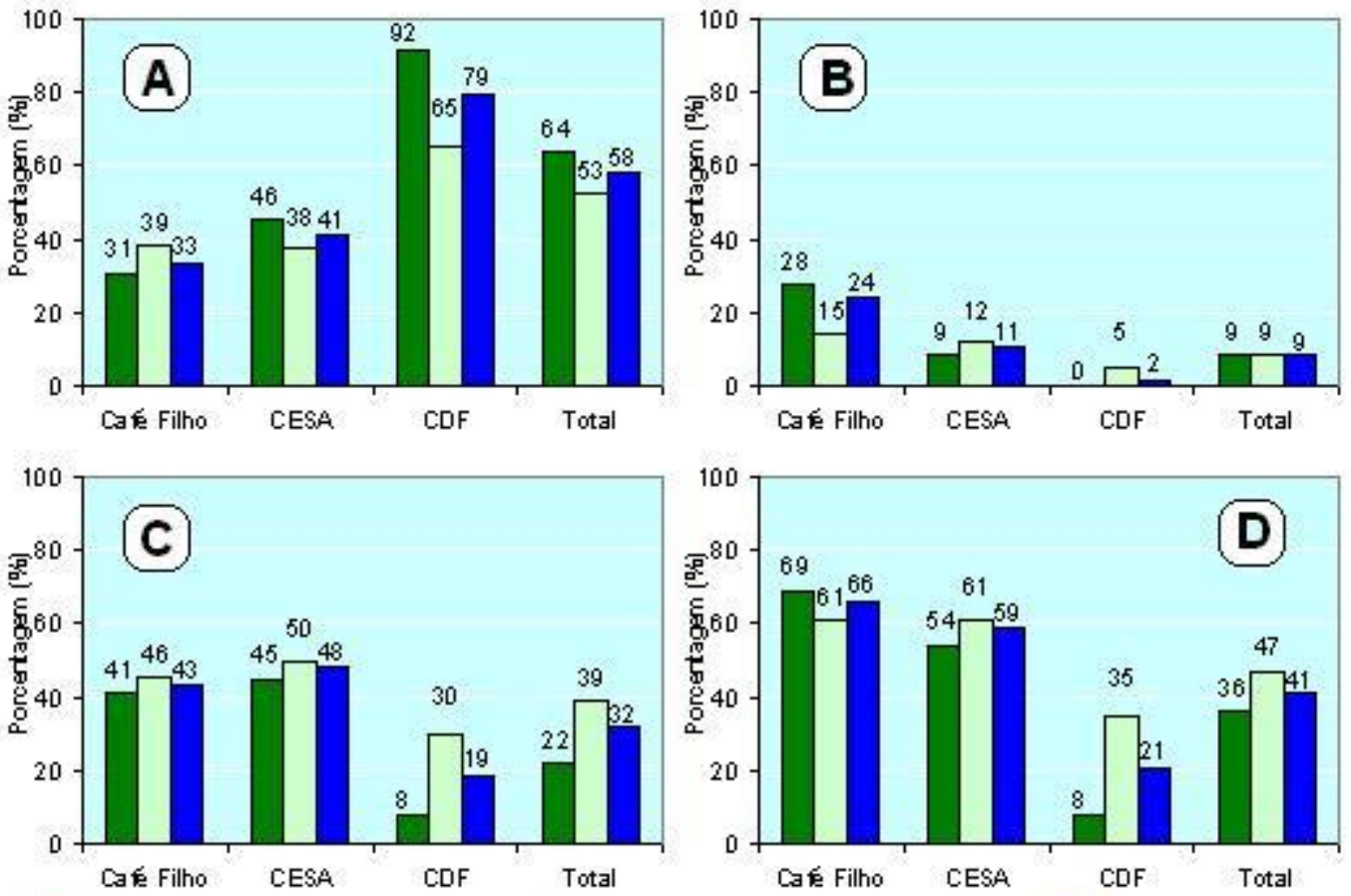

Desenhos anteriores à atividade

Desenhos posteriores à atividade

Total de desenhos

Figura 18 - Gráficos expressando os valores percentuais aproximados dos desenhos confeccionados por categoria:

A - categoria 1; B - Categoria 2; C - Categoria 3; D - Categoria 2 e 3 juntas.

Com respeito a assimilação do conteúdo teórico abordado, os números evidenciam um resultado positivo. No geral, entre os desenhos anteriores e posteriores, houve um decréscimo de 16,5\% de desenhos que incluem o homem e/ou algum elemento antrópico ao conceito de meio ambiente - Categoria $2+3$. Entretanto, este decréscimo é devido à discrepância na quantidade de desenhos entre o CDF e as demais escolas. Para as escolas Café Filho e CESA, presume-se, que parte do conteúdo pôde ser absorvido, pela expressão deste nos desenhos confeccionados. 
Para as escolas CESA e CDF, ocorre um resultado positivo em todos os quatro gráficos em relação a comparação dos desenhos anteriores e posteriores a atividade (decréscimo na categoria 1 e acréscimo nas categorias 2 e 3). Estas foram justamente nas quais houve a execução da palestra entre a realização dos desenhos. Consequentemente, foram repassadas para os estudantes concepções do meio ambiente de uma forma mais ampla, com o intuito de despertar a atenção e a reflexão dos desenhos com a realidade ambiental. Nota-se que, em relação aos desenhos confeccionados pela turma da escola Café Filho, houve um decréscimo na Categoria 2 entre os primeiros e segundos desenhos realizados. Vale salientar que a realização da palestra, nesta última, ocorreu após a confecção dos desenhos. Assim, a aplicação temporal diferenciada da metodologia infere uma diferença significativa do resultado exposto nos desenhos - verifica-se a possibilidade da influência positiva da aplicação da palestra entre a confecção dos desenhos.

Os valores do gráfico ainda mostram que o grau de conscientização ambiental, para estudantes do ensino fundamental, não está obrigatoriamente ligada ao padrão de ensino (pressupondo-se um melhor padrão das escolas particulares em relação às públicas). Observa-se que para as escolas Café Filho e Cesa, os desenhos estão relacionados, em maior quantidade, justamente às categorias 2 e 3.

O plantio das mudas é uma etapa da atividade na qual se concentram boa parte dos resultados almejados e obtidos. A atividade prática da arborização trabalha a educação informal, e é durante o plantio que se apresenta com maior intensidade a possibilidade da contribuição para a formação da consciência ambiental. Isto porque o estudante pode perceber fatores marcantes e previamente abordados na exposição teórica. Ou seja, a atividade do plantio permite trabalhar, com os estudantes, diversos aspectos e impactos ambientais sentidos na prática. Segundo Piletti (1991) apud Dias (1992, p. 130), aprendemos através dos nossos sentidos, sendo:

$$
\begin{aligned}
& \text { - } \quad 83 \% \text { através da visão, } \\
& \text { - } \quad 4 \% \text { da audição, } \\
& \text { - } \quad 3,5 \% \text { da olfação, } \\
& \text { - } \quad 1,5 \% \text { do tato e } \\
& \quad 1 \% \text { da gustação. }
\end{aligned}
$$

Ainda afirma que retemos apenas:

- $\quad 10 \%$ do que lemos,

- $\quad 20 \%$ do que ouvimos,

- $\quad 30 \%$ do que vemos,

- $\quad 50 \%$ do que vemos e executamos,

- $\quad 70 \%$ do que ouvimos e logo discutimos e

- $\quad 90 \%$ do que ouvimos e logo realizamos,

mostrando assim, o quanto é importante se trabalhar com a prática também, principalmente dentro da área ambiental.

Comprovou-se que o ato de plantar uma árvore constitui-se, muitas vezes, numa novidade para os estudantes, pelo menos na prática. Em maioria, por ser um momento inédito, os 
estudantes sentem grande estímulo em por mãos à obra e satisfazer curiosidades as mais diversas.

Durante a execução de todas as etapas do plantio, os coordenadores buscaram interagir com os estudantes. São transmitidas, em linguagem mais simples, informações como, por exemplo, esta contida em Souza (2005, p. 20):

\footnotetext{
"As plantas absorvem o gás carbônico do ar e liberam oxigênio por meio do processo de fotossíntese, contribuindo para a renovação de nossa atmosfera. As plantas também são úteis para abafar o ruído produzido pelo trânsito e pelas pessoas, além de proporcionar refúgio e alimento à sua fauna, tão indispensável para manter o equilíbrio biológico.”
}

Segundo Souza (2005, p. 28), “as características do meio ambiente podem ser melhoradas pela introdução e manutenção de vegetação nas cidades, causando um efeito de reaproximação da natureza e os seus benefícios intrínsecos.”; e Santos (2006):

\footnotetext{
"Mais que uma mera fonte de prazer e atividade lúdica, a arborização de ruas e outras áreas comuns das cidades é um gerador de alimento para diversas espécies de animais (mamíferos, aves, insetos) - cuja dieta depende dos frutos e do néctar de inúmeras árvores nativas do Brasil, além das inúmeras espécies que foram sendo introduzidas em nosso país por tantos e tantos anos (as chamadas espécies exóticas ou alóctones, em oposição às espécies nativas ou autóctones).”
}

Todas as atividades de arborização foram realizadas no período vespertino e em áreas abertas. A presença do sol e execução de exercício físico imprime nos estudantes a sensação de calor. Isto as possibilita, gradualmente, notar a diferença entre áreas pouco arborizadas, a sombra de uma árvore e bem arborizadas. Albrecht (1998, p. 21) afirma que “A questão do conforto ambiental está na necessidade que as pessoas sentem em ter uma árvore em frente à sua residência, pois esta, além de fornecer sombra, produz efeito estético e influencia no estado de ânimo, com o contraste da dinâmica fisiológica da vegetação sempre em modificação, em relação à construção”. Através dessa sensação, procurou-se trabalhar a imaginação dos estudantes e a expansão desse entendimento em nível local, regional e global. Procurou-se fazer com que o estudante entendesse as relações causa-efeito que determinam a sensação, estabelecendo-se a interligação ambiental existente entre as ações antrópicas e suas conseqüências no meio.

Outro instrumento utilizado na atividade para educação ambiental foi o folheto que acompanha as mudas. Além de todo conteúdo do folheto, significou o registro da atividade da qual os estudantes participaram. Funcionou também como mais uma ferramenta na criação do vínculo do estudante naquele determinado momento.

Ao término do plantio, no momento de interação, trabalhou-se coletivamente a responsabilidade sobre as mudas por eles plantadas, bem como sobre as que serão plantadas futuramente. O trabalho compreendeu uma breve exposição teórica e dinâmica, envolvendo perguntas e respostas. Esse momento visou fazê-los compreender que temos responsabilidade por nossas ações e que elas, sejam negativas ou positivas, acarretarão conseqüências para o ambiente (DIAS, 2004, p. 326).

\section{CONSIDERAÇÕES FINAIS}

O objetivo maior proposto foi o desenvolvimento da construção da educação ambiental, com estudantes de escolas públicas e particulares, através de uma perspectiva 
metodológica empregada pelo Projeto “Nativas no Campus” (PNC). Este projeto está pautado na sensibilização dos participantes para sua interação com o meio ambiente e conseqüente conscientização ambiental. Acredita-se que a experimentação prática de atividades ligadas à educação ambiental permite justamente o proposto: valorização do sentimento.

A vivência de uma atividade ambiental promove um despertar para as questões relacionadas ao meio ambiente e a educação ambiental é sentida por todos, tanto por quem recebe, como por aqueles que a fazem. Como executor das atividades, transmitir o conteúdo reforça a compreensão e o ganho de experiência, permite aprender a transmitir melhor, ou seja, a ser um disseminador.

Quanto aos estudantes, percebeu-se uma grande afinidade com os trabalhos desenvolvidos e uma motivação em querer conhecer sobre o meio ambiente, sobre os aspectos naturais relacionados a nossa vivência diária, especialmente para os estudantes das escolas públicas.

Percebendo a atividade como um todo, constata-se que o sucesso da mesma é dependente de todos os quatro momentos. Isto porque a ambientação dos estudantes é gradativa e, para que haja um bom grau de assimilação, se faz necessário que haja um clima de harmonia. Assim, é importante se trabalhar cuidadosamente tanto a recepção, como desenvolvimento e fechamento da atividade, de forma a fazer de cada momento um passo para se construir a conscientização ambiental nos estudantes.

\section{REFRÊNCIAS BIBLIOGRÁFICAS}

1. ALBRECHT, J. M. F. Análise funcional, composição arbórea e manejo da malha viária das áreas verdes da cidade de São Carlos-SP. Tese de doutorado. PPGERNUFSCAR. São Carlos - SP, 1998.

2. BERNA V. Como fazer educação ambiental. São Paulo - SP: Paulus, 2001.

3. BRASIL, MINISTÉRIO DA EDUCAÇÃO. Ciências da natureza, matemática e suas tecnologias.- Orientações curriculares para o ensino médio, v. 2. Brasília - DF : Ministério da Educação, Secretaria de Educação Básica, 2006, 135 p.

4. BRASIL, MINISTÉRIO DA EDUCAÇÃO. Parâmetros Curriculares Nacionais: Meio Ambiente: Saúde/ Ministério da Educação. Secretaria de Educação Fundamental. $3^{\mathrm{a}}$ ed. Brasília - DF: A secretaria, 2001.

5. CARVALHO,R.I.B.. O professor, a televisão e o vídeo: um estudo da mediação pedagógica em uma instituição de ensino superior. In: Congresso Brasileiro de Ciências da Comunicação, 28., 2005. Rio de Janeiro - RJ. Anais... São Paulo: Intercom, 2005. CDROM.

6. CESTARO, L. A. Comunicação pessoal. Natal - RN, 2005.

7. DIAS, G. F. Educação Ambiental, princípios e práticas. 3. ed. São Paulo - SP: Gaia, 1992.

8. DIAS, G. F. Educação Ambiental, princípios e práticas. 9. ed. São Paulo - SP: Gaia, 2004. 
9. Dicionário Aurélio Eletrônico Século XXI versão 3.0. Editora Nova Fronteira, novembro de 1999. CD-ROM.

10. GOHN, M. G. Educação não-formal, participação da sociedade civil e estruturas colegiadas nas escolas. Rio de Janeiro - RJ: Ensaio, v.14, n.50, p. 27-38, 2006.

11. MARTINS JUNIOR, J. P.; DANTAS, H. O índice de participação e a importância da educação. Campinas - SP: Opin. Publica, v. 10, n. 2, 2004. Disponível em: $<$ http://www.scielo.br/scielo.php?script=sci_arttext\&pid=S0104-627620040002000 05 \&lng=en\&nrm=iso>. Acesso em: 19 Set. 2006.

12. MASCARO, L; Mascaró, J. Vegetação urbana. Porto Alegre - RS: EDELBRA, 2002.

13. MEDINA, N. M. Educação ambiental: uma metodologia participativa de formação. Petrópolis - RJ: Vozes, 1999.

14. MERGUlHÃO, M.C.; VASAKI, B.N.G. Educando para a Conservação da Natureza. Sugestões de Atividades em Educação Ambiental. São Paulo - SP: EDUC, 2002.

15. MIGOTTO, F. Educação ambiental na escola e a formação de cidadãos conscientes. São João da Boa Vista - SP: Centro universitário da fundação de ensino Octávio Bastos, 2004.

16. NATAL. Plano de Arborização das Áreas Verdes Públicas para a Cidade do Natal - Proposta Preliminar. Natal - RN: Fundação do Meio Ambiente do Natal/ Secretaria Especial de Meio Ambiente e Urbanismo - SEMURB, 2004.

17. PAIVA, H. N.; GONÇALVES, W. Implantação de arborização urbana. Viçosa MG: UFV, 2001, v.17.

18. PHILIPPI, A. J.; PELICIONI, M. C. F. Educação ambiental e sustentabilidade. Barueri - SP: Manole, 2005.

19. PHILIPPI, A. J.; PELICIONI, M. C. F. Educação ambiental: desenvolvimento de cursos e projetos. 2 ed. São Paulo - SP: Signus editora, 2002.

20. REIGADA C., TOZONI M. F. C. Educação Ambiental para Crianças no Ambiente Urbano: Uma Proposta de Pesquisa-Ação. São Paulo - SP: Ciência \& Educação, v. 10, n. 2, p. 149-159, 2004.

21. SANTOS F. S. Qual a importância da arborização urbana?, Disponível em:<http://www.arscientia.com.br/materia/ver_materia.php?id_materia. Acessado em 14 ago. 2006.

22. SÃO PAULO. Guia de arborização urbana. São Paulo - SP, 2004.

23. SECRETARIA MUNICIPAL DE MEIO AMBIENTE - SMAM. Plano Diretor de Arborização de Vias Públicas. Porto Alegre-RS: SMAM, 2000.

24. SERRANO C; MENDONÇA, R. (Org.). A educação pelas pedras: ecoturismo e educação ambiental.São Paulo - SP:Chronos, 2000.

25. SOUZA, M. dos S. Arborização urbana do conjunto Cidade Satélite. Monografia, UFRN. Centro de Ciências Humanas, Letras e Artes - Departamento de Geografia. Natal RN, 2005.

26. TALAMONI, J. L. B.; SAMPAIO, A. C. S. (org.). Educação Ambiental: da prática pedagógica à cidadania. São Paulo-SP: Escrituras, 2003. 
27. ULMAN J. O pensamento educativo comtemporaneo. Tradução de Olga Pombo. Paris Vrin 1982, pp.9-26. Tradução de: La pensée éducative contemporaine.

28. UNESCO. Congresso Internacional UNESCO/PNUMA sobre la educacion y la Formacion Ambientale, Moscou. In: Educação Ambiental, Situação Española e Estratégia Internacional. DGMA - MOPU. Madrid , 1987

29. VASCONCELLOS, M. D. Sociology of education in France: a productive course. Educ. Soc., Campinas - SP, v. 24, n. 83, 2003. Disponível em: $<$ http://www.scielo.br/scielo.php?script=sci_arttext\&pid=S010173302003000200013\&lng =es\&nrm=iso>. Acesso em: 19 set. 2006.

30. VITÓRIA . Plano diretor de arborização e áreas verdes. Vitória - ES, 1992. 97p. 